\title{
Phase relationship between sea level and abrupt climate change
}

\author{
Francisco J. Sierro $^{a}{ }^{*}$, Nils Andersen ${ }^{b}$, Maria A. Bassetti ${ }^{c}$, Serge Bernéc, ${ }^{\mathrm{f}}$, Miquel Canals ${ }^{d}$, Jason H. \\ Curtis $^{\mathrm{e}}$, Bernard Dennielou ${ }^{f}$, Jose Abel Flores $^{\mathrm{a}}$, Jaime Frigola ${ }^{\mathrm{d}}$, Beatriz Gonzalez-Mora ${ }^{\mathrm{a}}$, Joan $\mathrm{O}$. \\ Grimalt $^{\mathrm{g}}$, David A. Hodell ${ }^{\mathrm{e}}$, Gwenael Jouet ${ }^{\dagger}$, Marta Pérez-Folgado ${ }^{\mathrm{a}}$ and Ralph Schneider ${ }^{\mathrm{h}}$
}

\footnotetext{
a Department of Geology, University of Salamanca, 37071 Salamanca, Spain

${ }^{b}$ Leibniz Laboratory for Radiometric Dating and Isotope Research, Christian-Albrechts Universität zu Kiel, MaxEyth-Str. 11, 24118 Kiel, Germany

c Laboratoire IMAGES (BatU), Université de Perpignan, 52 Avenue Paul Alduy, 66860 Perpignan Cedex 9, France

${ }^{d}$ G.R.C. Marine Geosciences, Department of Stratigraphy, Paleontology and Marine Geosciences, Campus de Pedralbes, University of Barcelona, 08028 Barcelona, Spain

e Department of Geological Sciences, University of Florida, Gainesville, FL 32611-2120, USA

${ }^{\dagger}$ IFREMER, GM, Laboratoire Environnements Sédimentaires, BP 70, 29280 Plouzané, France

${ }^{9}$ Department of Environmental Chemistry, Institute of Environmental Assessment and Water Research (IDAEA), Jordi Girona, 18, 08034 Barcelona, Spain

h Institut für Geowissenschaften, Christian-Albrechts-Universität zu Kiel, Ludewig Meyn-Str. 10, 24118 Kiel, Germany
}

*: Corresponding author : Francisco J. Sierro, Tel.: +34 9232944 97; fax: +34 9232945 14, email address : sierro@usal.es

\begin{abstract}
:
Direct traces of past sea levels are based on the elevation of old coral reefs at times of sea level highstands. However, these measurements are discontinuous and cannot be easily correlated with climate records from ice cores. In this study we show a new approach to recognizing the imprint of sea level changes in continuous sediment records taken from the continental slope at locations that were continuously submerged, even during periods of sea level lowstand. By using a sediment core precisely synchronized with Greenland ice cores, we were able to recognize major floods of the Mediterranean continental shelf over the past $270 \mathrm{kyr}$. During the last glacial period five flooding events were observed at the onset of the warmest Greenland interstadials. Consistent correspondence between warm climate episodes and eustatic sea level rises shows that these global flooding events were generated by pronounced melting of the Northern Hemisphere ice sheets, due to rapid intensification of Atlantic Meridional Overturning Circulation.
\end{abstract}

The method described in this study opens a new perspective for inter-hemispheric synchronization of marine climate records if applied in other continental margins from the Southern Hemisphere or the equatorial regions.

Keywords: Sea level change, abrupt climate change, Last Glacial period, Greenland ice cores 


\section{Introduction}

The last glacial period was imprinted by major cooling episodes known as Heinrich Events (HE) which involved massive iceberg discharges to the North Atlantic (NA) (Bond et al., 2003). Each of these events marked the end of a series of cold and warm oscillations (stadials and interstadials, respectively) which began with a prominent warming (Bond et al., 2003). This abrupt climate variability was caused by rapid changes in northward heat transport to the NA, due to oscillations in the Atlantic Meridional Overturning Circulation (AMOC) (Broecker 1994, 1998). Collapses of this circulation mode during HE were concurrent with Northern Hemisphere $(\mathrm{NH})$ coolings due to reduced inter-hemispheric heat exchange and prominent warmings in Antarctica (Blunier and Brook 2001). In contrast, the sudden AMOC resumptions after HE matched abrupt warming in Greenland and cooling in the Southern Hemisphere (Blunier and Brook 2001). However, many climate implications of these abrupt changes still need to be clarified, such as the extension and retreat of polar ice-sheets in the Northern or Southern hemispheres and subsequent global sea level variations. Contradictory results have been reported on the sea level changes associated with these $\mathrm{NH}$ abrupt transitions. Studies based on benthic stable oxygen isotopes using coral data for constraining the sea-level/oxygen isotope relationship have reported contradictory results, i.e. rises of 15-30 m either for stadials (Siddall et al., 2003; Rohling et al., 2008) or interstadials (Arz et al., 2007). Examination of coral reef terraces has also led to significant discrepancies about the timing of millennial sea level 
changes during MIS (Marine Isotope Stage) 3 (Yokoyama et al., 2001; Chappell 2002; Thomson and Goldstein 2005, 2006).

What we are reporting here is a new approach for investigation into sea level changes and abrupt climate variability during the last glacial period. The study of condensed layers (CLs), and $\delta^{18} \mathrm{O}$ in planktic and benthic foraminifera in cores collected in the Gulf of Lions continental slope provides unambiguous records of sea-level change and climate variation.

\section{Gulf of Lions Continental margin}

The Gulf of Lions is a stable margin, distant from the former ice sheets and therefore scarcely influenced by glacio-isostatic effect (Lambeck and Bard 2000), which is more than an order of magnitude lower than the glacio-eustatic change recorded since the maximum glaciation. This region of Southwest France, located south of the Rhone delta (Figure 1), is characterized by a wide continental shelf $(70 \mathrm{~km})$ that was largely subaerially exposed during the Last Glacial Maximum (Rabineau et al. 2005; Jouet et al., 2006; Bassetti et al., 2006, 2008; Berne et al., 2007).

The shelf accommodation space in the Gulf of Lions, that is, the volume available to store sediment and water on the shelf, has changed over the Late Pleistocene and Holocene, governing the spatial and temporal distribution of sedimentary units. Over the last decades several seismic investigations and dated sediment cores allowed to reconstruct the general architecture and stratigraphy of the Late Pleistocene deposits of the Gulf of Lions continental shelf (Tesson et al., 1990, 1993, 2000; Berné et al., 1998; Rabineau et al., 1998, 2005, 2006; Jouet et al., 2006; Bassetti et al., 2008). Those authors documented the superposition of various seismic sequences separated by major discontinuities formed in response to eustatic sea level changes. Each sequence consists of a seaward thickening wedge, showing progradation of the deltaic system (forced regressive deposits of Posamentier et al., 1992) during each of the successive sea-level falls of the last glacial periods (100 kyr climatic cycles). In figure 2 we show the uppermost seismic sequence formed during the last glacial cycle. Several seismic units were distinguished within this sequence: unit 147, which documents the overall progradation of the deltaic system during MIS3 and units 151/152, showing a rapid progradation of coastal sand deposits during MIS 2 (Jouet et 
al., 2006; Basseti et al., 2008). These coastal deposits pass seaward to the pelitic prodeltaic sediments recovered in the upper slope and studied here (Figure 2).

This regressive parasequence set is overlain by a series of transgressive parasequences that indicate a rapid retrogradation of the deltaic system from the outer to the inner shelf, more than $40 \mathrm{~km}$ landward, in response to the high rates of sea level rise during deglaciation (Gensous and Tesson 1997, 2003; Labaune et al., 2005, 2008; Berne et al., 2007). During the Bolling-Allerod-Younger Dryas period, a deltaic system developed in the middle shelf (Figure 2), which was named by Berné et al. (2007) as the Early Rhone Deltaic System. During the Holocene, the deltaic system retreated again a few km landward due to a resumption of sea level rise and a new deltaic system developed in the inner shelf (Figure 2). Each of these deltaic systems consists of clastic coastal sediments that pass offshore to prodeltaic pelitic deposits due to the large river supply of fine-grained, terrestrial components.

The present-day geometry of the Rhone deltaic system is determined by sediment flux with a typical sigmoidal form. In the vicinity of the Grand-Rhone river, the deltaic system is 40 to $50 \mathrm{~m}$ thick, with sedimentation rates higher than $4 \mathrm{~m} / \mathrm{kyr}$ due to the high sediment flux, but it thins rapidly seawards because the sediment flux decreases exponentially with the distance to the river mouth (main source of sediments) (Berné et al., 2002; Rabineau et al., 2005). The pelitic prodeltaic sediments pinch out offshore, marking what we call here the Prodelta Seaward Limit (PSL), which today is located at around $7 \mathrm{~km}$ from the coast at a water depth of $30 \mathrm{~m}$ (Figures 1, 2). In figures 1 and 2 we refer to this boundary as PSL 2 to distinguish it from PSL 1, which marks the offshore boundary of the Early Rhone Deltaic system at the time when it was abandoned. Beyond the PSL, there is almost no net sedimentation because the rate of sediment input is balanced by the rate of sediment output due to the action of bottom currents. All the clinoforms defining the internal geometry of the deltaic system, which are clearly separated landwards, converge at this point (Figure 2). Condensed sediments form offshore the PSL due to the slow accumulation of pelagic, coarse-grained skeletal material, which contrasts with the fine-grained pelitic sediments associated with the prodeltaic system (Bassetti et al., 2006). Offshore the PSL the 10-0 kyr time-interval is only represented by a thin veneer of biogenic, fine to medium sand forming a condensed deposit (Figure 2), which extends from the inner shelf to the upper slope (Bassetti et al., 2006). This thin, condensed layer overlies the Early Rhone Deltaic System (Berné et al., 2007) in the middle shelf. As illustrated in figure 2, the PSL of this ancient delta (PSL 
1) was located at that time at around $35 \mathrm{~km}$ from the coast, well away from the shelf edge, and consequently seaward of this boundary, condensed sedimentation has not been interrupted since the last deglaciation to the present.

\section{Materials and methods}

We studied a composite sedimentary record of Core MD99-2348 and Borehole PRGL1 ( $\left.40^{\circ} 29.84^{\prime} \mathrm{N} ; 4^{\circ} 1.69^{\prime} \mathrm{E}\right)$, both drilled at the same place, at a water depth of 300 $\mathrm{m}$ on the upper slope from the Gulf of Lions. Core MD99-2348 is $24 \mathrm{~m}$ long and was recovered on an interfluve between Herault and Bourcart/Aude Canyons during cruise IMAGES V of the R/V Marion Dufresne (Figure 1). Borehole PRGL1 was drilled at the same position within the framework of EU project PROMESS1. It reached a total length of $300 \mathrm{~m}$, of which the upper $130 \mathrm{~m}$ were analysed for this study. To elaborate the composite record we switched from Core MD99-2348 to Hole PRGL1 at 17.78 mbsf (meters below sea floor) and shifted PRGL1 depths $1.96 \mathrm{~m}$ upward because this is the offset between both depth scales at this depth.

Both cores were sampled every $10 \mathrm{~cm}$. Samples for isotope analyses and foraminifer counting were washed over a $63 \mu \mathrm{m}$ sieve and the residues were dried and dry-sieved again using a $150 \mu \mathrm{m}$ sieve. The $>150 \mu \mathrm{m}$ fraction was then split as many times as necessary to obtain an aliquot of approximately 300 specimens of planktic foraminifers. Samples were counted to calculate the relative percentages of the major planktic foraminifer taxa. All species of Globigerinoides, Orbulina universa, Globorotalia inflata, Globigerina rubescens, Globigerina digitata, Globigerina calida and Neogloboquadrina pachyderma (dextral) were grouped together to calculate the relative abundance of temperate to warm planktic foraminifers.

Approximately 2 to 20 specimens of Globigerina bulloides from the 250-350 $\mu \mathrm{m}$ size fraction and 2 to 10 individuals of Hyalinea balthica larger than $150 \mu \mathrm{m}$ were picked to measure oxygen and carbon isotope ratios. Foraminifer tests were soaked in $15 \% \mathrm{H}_{2} \mathrm{O}_{2}$ to remove organic matter, and cleaned sonically in methanol to remove finegrained particles. Samples from core MD99-2348 were analysed at the University of Florida. Isotope ratios were measured online using a Finnigan MAT 252 mass spectrometer. Analytical error was estimated to be $\pm 0.08 \%$ o for $\delta^{18} \mathrm{O}$ (expressed as \pm 1 standard deviation) by measuring 8 standards (NBS-19) with each carousel containing 38 samples. Samples from Borehole PRGL1 were analysed at Christian-Albrechts University of Kiel using a Finnigan MAT 251 mass spectrometer with an analytical 
error better than $\pm 0.07 \%$ or for $\delta^{18} \mathrm{O}$ measurements. All isotope results are reported in standard delta notation relative to V-PDB (Coplen, 1996). The percentage of fine-sand was calculated from the weights of 62-150 $\mu \mathrm{m}$ grain-size and dry sediment x 100 .

AMS ${ }^{14} \mathrm{C}$ analyses of core MD99-2348 were performed at the Lawrence Livermore National Laboratory (USA), while samples from hole PRGL1-4 were performed at the Poznan Radiocarbon Laboratory in Poland. Owing to the scarcity of planktic foraminifers, in most of the samples a mixture of calcareous biogenic shells, mostly planktic and benthic foraminifers, including some mollusc shells, was picked and soaked in $15 \% \mathrm{H}_{2} \mathrm{O}_{2}$ to remove organic matter and cleaned sonically in methanol to remove fine-grained particles. In a few samples, a single mollusc shell was dated. The Ages were calibrated with Marine04. ${ }^{14} \mathrm{C}$ data base (Hughen et al., 2004) up to $25 \mathrm{kyr}$, with Fairbanks0107 (Fairbanks et al., 2005) up to 45 kyr and with CalPal-2007 Hulu (Weninger and Joris 2008) for older samples, using the standard marine correction of 400 years (Table 1$)$.

\section{Results}

Grain-size and micropaleontologic analyses in core MD99-2348 show that sedimentation in the Gulf of Lions upper continental slope suddenly changed at around 14.8 kyr ago from clastic, clay-rich deposits with low contents of foraminifer tests to sandy, biogenic sediments mainly dominated by foraminifers (Figure 3). This lithologic change is parallel to a large decrease in the $\delta^{18} \mathrm{O}$ of $G$. bulloides. A small increase in grain size at around $16 \mathrm{kyr}$ ago is related to clastic sand and has no parallel increment of the foraminifer content.

The study of the composite record from core MD99-2348 and Hole PRGL1 revealed that other seven sandy-rich layers were deposited over the last $270 \mathrm{kyr}$ (Figure 4) which are related to periods of low $\delta^{18} \mathrm{O}$ values in G. bulloides. All these layers are also enriched in planktic foraminifers. By contrast, the periods of high $\delta^{18} \mathrm{O}$ values are related to clay-rich sediments with very low concentrations of planktic foraminifers.

Besides the above major sand-layers, another five layers were observed during the last glacial period with relatively high percentages of sand and lower amplitude increments in the concentration of planktic foraminifers (Figures 4, 7). All these levels occurred during MIS 3 and are also related to low $\delta^{18} \mathrm{O}$ values in G. bulloides.

The planktic foraminifer assemblages together with the $\delta^{18} \mathrm{O}$ of G.bulloides were analysed for the interval from 20 to $130 \mathrm{kyr}$ to reconstruct the impact of millennial-scale 
abrupt climate changes in the Mediterranean. In particular, the species characteristic of temperate to warm surface waters underwent rapid and high amplitude changes in relative abundance along the time interval studied (Figures 5, 6, 7).

\section{Age model: Synchronization of Mediterranean and Greenland climate records}

The age model used in our study was established by synchronizing the composite MD99-2348/PRGL1 records of Globigerina bulloides $\delta^{18} \mathrm{O}$ and abundance of temperate-to-warm planktic foraminifers to the North Grip ice core isotopes in Greenland (NGRIP members, 2004; Andersen et al., 2006; Svensson et al., 2008) (See Table 2 and Figure 6). This synchronization is based on the striking resemblance of all these records (Figures 5, 6, 7) and on data from previous studies that already demonstrate this synchronism, which is due to the rapid atmospheric connection between Greenland and the Mediterranean (Cacho et al., 1999; Perez-Folgado et al., 2003; Martrat et al., 2004; Sierro et al., 2005). The age scales GCIC05 (Andersen et al., 2006; Svensson et al., 2008) and NGRIP Group (NGRIP members, 2004) were used between 0-60 kyr and 60-120 kyr BP, respectively. Between 120 and $270 \mathrm{kyr}$, the age model was built by aligning the Globigerina bulloides $\delta^{18} \mathrm{O}$ record to the Specmap isotope stack (Martinson et al., 1987). In figure 4 we also used Specmap ages between 80 and 120 kyr to compare our results with global sea level records. Further refinement in isotope stages 6 and 7 was obtained by aligning the $\delta^{18} \mathrm{O}$ record of $G$. bulloides to that of ODP hole 977 in the western Mediterranean (Martrat et al., 2004). We also identified four peaks of the polar species Neogloboquadrina pachyderma (sinistral) which correlated with HE 2, 3, 4 and 6 (Figure 7D) as has been previously shown (Cacho et al., 1999; Perez-Folgado et al., 2003; Sierro et al., 2005). All tie points used for the alignment are shown in Table 2.

The Globigerina bulloides $\delta^{18} \mathrm{O}$ and planktic foraminifer records are parallel because they mainly record variations in Mediterranean SST. However, in case of discrepancy between both records, we used the foraminifer assemblages because the $\delta^{18} \mathrm{O}$ of sea water can be affected by other processes. In particular, a small discrepancy was observed at the top of HE4. The negative shift in $\delta^{18} \mathrm{O}$ usually associated to warming at the base of interstadials clearly occurred in this case during HE4, contemporaneous with abundant Neogloboquadrina pachyderma sin, whereas the disappearance of this species in combination with the increase of subtropical foraminifers mark the beginning of Greenland interstadial (GIS) 8. This oxygen isotope 
negative shift within HE4 was related to the impact of iceberg melting in the Atlantic as previously reported by Sierro et al., 2005.

Our chronology was further established by $29{ }^{14} \mathrm{C}$ AMS dates obtained from calcareous shells (Table 1). With the exception of a few samples mainly in the time span between 40 and $50 \mathrm{kyr}$, the offset between the ${ }^{14} \mathrm{C}$ calibrated ages and the NorthGrip tuned ages is small, being our calibrated ages between a few hundred years and $1 \mathrm{kyr}$ older than the NorthGrip tuned ages (Figure 8). This offset is consistent with that found in previous calibrations (Shackleton et al., 2004).

Based on this age model we estimated sedimentation rates, observing that they were very low during interglacial periods and increased progressively towards glacial times (Figures 4, 9).

\section{Discussion}

\subsection{Formation of the Holocene condensed layer.}

Various ${ }^{14} \mathrm{C}$ datings and the Globigerina bulloides $\delta^{18} \mathrm{O}$ record revealed that the sand layer recorded in the uppermost $50 \mathrm{~cm}$ of Core MD99-2348 (Figure 3) was deposited over the last $14.8 \mathrm{kyr}$, under extremely low sedimentation rates. In contrast, sediments from the last glacial maximum typically consist of muds that were deposited at high sedimentation rates $(2.5 \mathrm{~m} / \mathrm{kyr})$. Radiocarbon datings revealed that this clay accumulated rapidly over the Last Glacial Maximum (LGM) (Figure 3). During that time the coastline was very close to the shelf-break (Jouet et al, 2006; Berne et al., 2007) and there was almost no space on the shelf to accommodate the prodeltaic muds and coastal sediments supplied by the river. River mouths (Rhone and smaller rivers) opened at the shelf-edge (Jouet et al., 2006; Berne et al., 2007, see Figure 2), supplying millions of cubic meters of clay to the upper slope that diluted the concentration of planktic shells in the sediment (Figure 3). Tracing of seismic reflectors to the continental shelf shows that these are distal prodeltaic sediments deposited in the upper slope at the time of rapid progradation of the deltaic system during the LGM (seismic unit 152, Figure 2). However, the rapid elevation of sea level due to $\mathrm{NH}$ ice-sheet collapse during melt-water pulse 1A (Fairbanks, 1989) inundated the shelf, generating enough space there to accommodate all deltaic deposits. The coastline and prodeltaic deposits migrated landward, especially from 14.5 to 7 kyr ago when maximum flooding occurred, gradually moving the place of main deltaic deposition away from the shelf edge and the slope (Berne et al, 2007). As a result, terrigenous fine-grained particles no 
longer reach the upper slope, initiating a long period of sediment starvation and the deposition of the condensed layer that we observed on top of our core. Sediment accumulation was only maintained by the slow flux of pelagic skeletal material, mainly planktic and benthic foraminifers and other biogenic material. In terms of sequence stratigraphy this layer constitutes the condensed section formed at times of maximum rates of relative sea level rise (Loutit et al., 1988). During the last glacial maximum prodeltaic particles were buried very rapidly without transformation by bottom currents. In contrast, sedimentation rates during the Holocene are lower than $0.1 \mathrm{~m} / \mathrm{kyr}$ and the particles remained thousands of years near the surface. In consequence, bottom currents caused a great impact on their physical and chemical properties, washing the finegrained component and concentrating the coarse-grained particles, as has been previously reported in other regions (Sierro et al., 1999).

\subsection{Formation of condensed layers at times of high sea levels over the last $270 \mathrm{kyr}$}

To explore the presence of older condensed layers formed at times of elevated sea levels, we analysed the percentage of fine-sands in the MD99-2348-PRGL1 composite record. This study revealed that dominant clay sedimentation was interrupted by the deposition of seven prominent sandy, foraminifer-rich layers during each of the major interglacial isotope stages (Figure 4) of the last $270 \mathrm{kyr}$, clearly demonstrating the relationship between these condensed layers and global eustatic highstands during isotope substages 5.1, 5.3, 5.5, 7.1, 7.3, 7.5. They reflect again the landward migration of the coastline and the consequent migration of fine-grained prodeltaic sedimentation forced away from the shelf edge, leaving sand-rich sediments on the upper slope which become concentrated in planktic foraminifer tests. These condensed levels largely contrast with the fine-grained, terrigenous muds recorded in glacial stages 2, 4, 6 and 8 (Figure 4), reflecting the seaward migration of prodeltaic deposits to the upper slope.

Carbonate-free analyses also showed high contents of fine-sand in the condensed layers, indicating that these layers were not generated solely by higher concentrations of planktic foraminifers or other biogenic components (unpublished data).

High sedimentation rates are recorded during periods of maximum glaciation, in MIS 2, 4, 6 and 8 (Figure 4G), in response to the rapid progradation of the deltaic system towards the shelf edge, as the deltaic system could no longer be accommodated in the shelf during periods of limited accommodation space due to the sea level drop. Consequently, the sedimentation rate record shows great similarity with global records 
of sea level change as it mainly reflects the sequences of progradation and retrogradation of the deltaic system in the shelf in response to changes in shelf accommodation space.

The three prominent CLs formed during isotope stage 5 (Figure 5) were synchronous with abrupt warming in Greenland, marking the base of Greenland interstadials (GIS) 26, 24 and 21. The two CLs associated with GIS 24 and 23 (Figure 5E) were probably related to sea-level rises occurring during substages 5.33 and 5.31 .

\subsection{Constraints on condensed layer formation in the Gulf of Lions continental margin and global eustatic changes}

Changes from pelitic prodeltaic deposits to condensed sediments in the upper slope and vice-versa were driven by the retrogradation and progradataion of the deltaic system and the subsequent landward or seaward shift of the PSL. The progradation or retrogradation of the deltaic system is, in turn, driven by the interplay of eustatic sea level change, tectonic movement of the continental margin, and variations in sediment supply by rivers that continuously change the balance between the generation/reduction of accommodation space and the sediment filling of this space. However, extensive seismic studies have shown that eustatic changes played the dominant role in the Gulf of Lions (Tesson et al., 1990; Posamentier et al., 1992; Gensous and Tesson, 2003; Rabineau et al., 2005, 2006; Jouet et al., 2006; Berne et al., 2007; Bassetti et al., 2008), because the long term subsidence typical of a passive continental margin acted in a longer time scale than the climatic cycles studied here (Jouet et al., 2008) and the Gulf of Lions is distant from the major glacial ice sheets. In addition, sediment or water loading only amplifies the effect of global eustatic changes (Jouet et al., 2008).

Consequently, the generation/reduction of space in the shelf is a function of the magnitude and rate of sea level change and the rate of space filling by the sediment flux. When the rate of generation of new space due to eustatic sea level rise is higher than the rate at which this new space is filled by sediments, the deltaic system will retreat landward. By contrast, the deltaic system will prograde when the accommodation space diminishes, either because of a sea level drop or when the rate of generation of new space becomes lower than the rate of sediment filling of this space.

Sequences of progradation/retrogradation of the deltaic system across the shelf are recorded in the slope by sequences of increasing/decreasing sedimentation rates. 
However, as long as the space available in the shelf is large enough to accommodate the whole deltaic system, these sequences of progradation or retrogradation will have no major impact on the type of sediments deposited in the slope because the PSL always remains inside the shelf and the pelitic prodeltaic deposits never reach the upper slope. By contrast, when the space available in the shelf decreases under a certain threshold, either because of space reduction due to a sea level drop or through the filling of the existing space by sediments, the deltaic system can no longer be accommodated in the shelf and the PSL crosses the self-edge, leaving fine grained prodeltaic deposits in the upper slope. This minimum space necessary to accommodate the entire deltaic system within the shelf is therefore the threshold that has to be crossed to switch "on" and "off" the deposition of condensed sediments in the slope, marking the bottom and top of CLs. During MIS 2, 4, 6 and 8, the sea level fall was so large that reduced the space available in the shelf below the threshold required to accommodate the deltaic system within the shelf and a large portion of the prodelta had to be accommodated in the slope, as shown by the high sedimentation rates recorded at those times (Figure 4G). In addition to the sea level fall, the accommodation space was further reduced by rapid sediment filling due to erosion of the subaerial coastal sediments, previously deposited. At these lowstand times, the space available in the shelf was well below the threshold and therefore formation of condensed layers is not expected, unless a prominent and rapid sea level rise takes place. Sea level rises of small amplitude during these lowstand periods did not generate enough space in the shelf to form CLs in the slope.

Because of the rapid elevation of sea level during the main interglacial substages of MIS 1, 5 and 7 the new space generated soon reached the threshold required to accommodate the deltaic system within the shelf, triggering CL deposition in the slope when the PSL migrated towards the shelf. The accommodation space existing in the shelf during these highstand periods was so large that it remained well above the threshold for a long time. Condensed deposition lasted until this threshold was reached again when the new space was filled by sediments or largely reduced due to the ensuing sea level drop.

At times of intermediate sea levels, however, the space available in the shelf was very close to the threshold necessary to retain the deltaic system in the shelf and, consequently, small amplitude changes in sea level may result in various fluctuations from pelitic to condensed deposits in the slope and vice-versa. This can be the case for example of the two CLs associated with GIS 24 and 23 (Figure 5E) that were probably related to sea level rises of small amplitude occurring during substages 5.33 and 5.31 . 
The low sedimentation rates during that interval indicates that the deltaic system was mainly placed within the shelf and the progradation of pelitic prodeltaic sediments during the stadial that follows GIS 24 suggests that the space existing in the shelf was rapidly filled by the rivers. However, this progradation was stopped during GIS 23 as the PSL moved back towards the shelf again.

Changes in the rate of sediment supply may also result in progradation or retrogradation of the deltaic system, however, the impact of these changes is of much lower magnitude than that of eustatic changes. A sudden drop in sediment supplied by the Rhone or small Languedocian and Pyrenean rivers may result in retrogradation of the deltaic system and the formation of condensed layers. However, all condensed layers were formed at times of warmer climates throughout the Mediterranean, which are typically characterized by much higher rainfall and much greater river sediment flux (Cacho et al., 2000; Sanchez-Goñi et al., 2002; Sierro et al., 2005).

\subsection{Rapid flooding of the continental shelf during the longest interstadials of the last glacial period in Greenland.}

Besides the above major CLs, five smaller-scale CLs are observed during the last glacial period (Figure 7E, F). These CLs are concurrent with the warmest Greenland interstadials (GIS 16, 14, 12, 8 and 7). The match is independent of age model, since the CLs and climatic records (e.g., \% fine sand, abundance of planktic foraminifers, $\delta^{18} \mathrm{O} G$. bulloides, temperate-to-warm foraminifers, Figure 7B, C, E, F) are obtained from the same composite core.

Correlation of seismic reflectors indicates that these CLs formed in the slope during the time of deposition of seismic units 147 and 151/152 in the shelf, which recorded the overall progradation of the deltaic system in response to the long-term sea level fall from MIS 3 to the LGM (Jouet et al., 2006; Bassetti et al., 2008). Seismic lines show that the coastline advanced more than $30 \mathrm{~km}$ towards the shelf edge during that period (Figure 2). However, the formation of CLs in the upper slope indicates that this progradation was interrupted at least five times during MIS 3, when the rate of generation of new space in the shelf was high enough to overcome the rate of sediment supply. We conclude that these CLs formed at times of rapid sea level rise and highstand during MIS 3 that triggered short-term landward migrations of the deltaic system, leaving starved sediments on the slope. These millennial sea level changes are 
also recorded by seismic reflectors that illustrate the landward and seaward migrations of the coastline (Jouet et al., submitted).

Again, it could be argued that a lower sediment delivery during major interstadials of MIS 3 might have caused starvation in the upper slope. However, average annual rainfall increased during interstadials (Cacho et al., 2000, Sanchez Goñi et al., 2002; Sierro et al., 2005) and consequently sediment supply should have been higher. Many of the reconstructions of millennial sea level change during MIS3 (Shackleton et al., 2000; Yokoyama et al., 2001; Chappel 2002; Siddall et al., 2003; Thomson and Goldstein, 2005; Arz et al., 2007) share the same variability pattern, recording four sea level fluctuations of 20-30 m magnitude that follow the cold/warm sequence of Bond cycles (between HE6, HE5a, HE5 and HE4) (see Clark et al., 2007 or Siddall et al., 2008 for a review). However, significant discrepancies about the timing and phase relationship with Greenland or Antarctica still exist. Our CL stratigraphic record also shares the same structure, with a CL formed immediately after Heinrich events 6, 5a, 5 and 4 (Figures 7, 9), and a new one in GIS 7. The sedimentation rate also confirms this pattern, showing four sequences of increasing sedimentation rate that were related with periods of deltaic progradation during these four Bond cycles (Figure 9C). By contrast, reduced sedimentation rates were linked to deltaic retrogradation at times of sea level rise.

Because CLs formed at times of low sedimentation rates, time resolution of our analyses sharply decreases at the bottom of these layers. Hence, it may be argued that CLs deposition could have started during HE, however, our records document that the peaks in $N$. pachyderma sin. associated with HE in the Mediterranean (for example in HE 4 and HE6) clearly predate the CLs. In addition, the negative oxygen isotope anomalies recognized in the middle of HEs and attributed to the injection of large volumes of freshwater carried by icebergs from the Atlantic (Sierro et al., 2005) is visible in HE 4, HE5 and HE6 and they too unambiguously predate the corresponding CLs. On the other hand, the existence of a small lag between abrupt warming in Greenland and the sea level rise cannot be resolved with our records because of the low time resolution during CL deposition.

The onset of CL formation during MIS 3 was therefore linked to periods of sea level rise that generated new accommodation space, but only if the space created exceeded the threshold necessary to completely accommodate the deltaic system within the shelf. This threshold could only be reached at times of high amplitude sea level rise and, 
obviously, before the maximum sea level was reached. Based on the sea level reconstruction of Siddall et al. (2003), the four main rises in sea level during MIS3 were relatively abrupt; they took place in only 300 to 700 yrs. This significantly constrains the timing of these rises since they must necessarily be correlated with the bottom of our CLs and hence with the onset of major interstadials in Greenland. The top of CLs reflects the renewal of deltaic progradation towards the slope, when the space generated during the sea level rise was filled by sediments supplied by the rivers. In consequence, the duration of CLs depends on the magnitude of the space generated in the shelf, which is a function of the amplitude of sea level rise, and the space filling rate, which is a function of sediment delivery by the main rivers. In particular, the CL of GIS 12 is very thin and placed at the bottom of the interstadial, suggesting that either the space generated in the shelf was small or the rate of sediment filling very rapid. This $\mathrm{Cl}$ illustrates the straight relationship between abrupt warming in Greenland and maximum rate of eustatic sea level rise because it was only at the onset of GIS 12 when the rate of generation of new space in the shelf overcame the rate of filling.

The CL of GIS 7 may be the result of a sea level rise of smaller amplitude, formed when the PSL was close to the shelf edge. The deltaic progradation towards the slope that followed GIS 8 was starting when a new sea level rise of small magnitude might have caused a new landward shift of the PSL. As mentioned in section 5.3, this may happen when the space available in the shelf is very close to the threshold necessary to accommodate the whole deltaic system within the shelf.

Although the sea level may have started to rise during the Heinrich events, (this could have been the case during HE4, with a sudden drop in sedimentation rate), our study demonstrates that the periods of highest rate of sea level rise, and certainly the times of highstand are synchronous with the prominent interstadials in Greenland that followed the HE. Only during these prominent interstadials, the amplitude and rate of sea-level rise was sufficient to accommodate the whole deltaic system in the shelf. By contrast, condensed layers never formed during HE, showing that even if the sea level rose, either the elevation was of relatively small amplitude or the rising rate was too slow.

In order to gain a general picture about the timing of millennial-sea level change during MIS 3 we tied the Red Sea chronology (the records of both Siddal et al., 2003 and Arz et al., 2007) to the timing of our condensed layers, assuming that the bottom of our condensed layers was synchronous with the midpoint of the four major and most rapid sea level rises recorded in the Red Sea (Figure 9D). 
With the new correlations several conclusions can be drawn. The MIS4-3 transition, which is very apparent in all sea level records, must be correlated with GIS 16 in Greenland (Figure 9). Strong discrepancies exist between different sea level records about the timing of this event (see Siddall et al., 2008 for a review). Our data are in excellent agreement with the timing reported for this event by Arz et al. (2007) and the Specmap record (Imbrie et al., 1984), and is 3 kyr younger than that reported by Siddall et al. (2003) and Chappell et al. (2002) (Figure 9).

The second sea level sequence in MIS 3 starts with a rapid sea level rise during GIS 14. This timing fits well with a sudden sea level rise reported by Siddall et al. (2003) and that of Chappell et al. (2002) (Figure 9). However, it is 2 kyr older than that reported by Arz et al. (2007). Age errors for this interval in the sea level reconstruction of Arz et al. (2007) may be high because their chronology is mainly based on only two points of minimum magnetic paleointensities.

Discrepancies in the timing of the other two sequences of sea level change between the different sea level reconstructions are smaller. Our data indicate that the two rapid sea level rises of 20-30 m amplitude reported by Siddall et al. (2003) during HE 5 and 4 should be slightly shifted towards a younger age (Figure 9). Our timing is more in agreement with the record of Arz et al. (2007) for these two sequences.

Our results show that the Bond cycles (Bond et al., 2003) are intrinsically linked to sequences of global sea level change, starting with sea level rises at the onset of the most prominent warming events in Greenland, probably triggered by massive ice-sheet collapse in the NH. The high sea levels, which lasted from a few centuries to a few thousand years, were followed by a long-term period of ice-sheet growth. Based on the sedimentation rate record and our new chronology for the Red-Sea record of millennial sea level change (Figure 9), the minimum sea level, maximum extension of the icesheets, was reached at the onset of or during the HE. We speculate that the combination of increasing ice growth and lower sea levels could have eventually culminated with the destabilization of the ice sheets during HE, causing iceberg discharges and collapses of the MOC with its global climate implications.

Our results indicate that the negative values in the benthic $\delta^{18} \mathrm{O}$ record from the Portuguese margin that were tentatively associated with sea-level rises during $\mathrm{HE}$ (Shackleton et al., 2000) are more likely related to deep-water hydrographic changes (Skinner et al., 2003). A deep water $\delta^{18} \mathrm{O}$ decrease of $1 \%$, not associated with icevolume change, has been observed during HE1 and the Younger Dryas (YD) (Skinner 
et al., 2003). Similar NA $\delta^{18} \mathrm{O}$ depletions in other HE could have been caused by the shut-down of the only source of high $\delta^{18} \mathrm{O}$ deep waters in the open North Atlantic and its replacement by low $\delta^{18} \mathrm{O}$ deep waters generated by brine formation either in the Southern Ocean (Skinner et al., 2003; Skinner and Elderfield 2007) or in the North Atlantic (Vidal et al., 1998; Dokken and Jansen 1999) without eliciting ice volume changes. New injection of high $\delta^{18} \mathrm{O}$ deep water near the base of major interstadials ended with these negative isotope anomalies during HE, explaining the main patterns of the benthic Atlantic $\delta^{18} \mathrm{O}$ records, including their phase relationship to Antarctica.

The CLs from the Gulf of Lions show a consistent correspondence between warm climate episodes and eustatic sea level rises for both glacial-interglacial periods and the stadial-interstadial stages of the last glacial period. This strong coupling between abrupt warming in the $\mathrm{NH}$ and rapid sea level rises at times when Antarctica was cooling (Blunier and Brook 2001) point to $\mathrm{NH}$ ice-sheet collapses as the main process leading to the sea level changes observed.

The events of sea level rise in the Gulf of Lions continental shelf, both at millennial scale and during major deglaciations, were synchronous with the northernmost shift of the intertropical convergence zone (ITCZ), as recorded by riverine Ti contributions in the tropical Atlantic (Peterson et al., 2000). A close comparison of CL data with changes in the AMOC represented by NA benthic $\delta^{13} \mathrm{C}$ records (Shackleton et al., 2000; Martrat et al., 2007) (see Figure 10), the position of the ITCZ in the tropical Atlantic (Peterson et al., 2000) and air temperature at NH mid-latitudes (Martrat et al., 2004) illustrates the close relationship between these flooding episodes and maximum AMOC strength, northward ITCZ shift and highest air temperatures at mid-latitudes during the warmest Greenland interstadials. These correspondences are consistent with climate models that predict a negative mass balance of $\mathrm{NH}$ ice-sheets in response to increasing northward heat transport (Schmittner et al., 2002; Kageyama and Paillard, 2005; Arz et al., 2007). Progressive AMOC reduction, which typically began after the warmest interstadials, was correlated with increasing ice-sheet growth, a southward shift of the ITCZ and lower air temperatures at mid-latitudes.

The concurrence of flooding events with high $\mathrm{CO}_{2}$ (Figure 10) suggests that this external forcing may have played a role in amplifying the negative mass balance of the ice-sheets initially triggered by AMOC intensification. Our results suggest that the Bond cycles are the response to sequences of increasing ice volume that modulated the 
impact of AMOC-driven climate events. Consecutive warming events driven by AMOC reactivations along each Bond cycle were of progressive lower amplitude as ice cover in the NH was more extensive.

Collapse of $\mathrm{NH}$ ice sheets must lead to synchronous global flooding of the continental shelves. Consequently, identification of similar CLs in other continental margins, especially in the tropical Pacific, will provide a powerful tool for interhemispheric synchronization of marine climate records and for testing models on the effect of ocean heat transport on ice-sheet dynamics.

\section{Conclusions}

In the present manuscript we report a new method for recognizing the imprint of sea level changes in continuous sediment records collected near the continental shelf, at locations that were continuously underwater, even during the periods of sea-level lowstand. This approach, in a sediment core that was precisely synchronized with Greenland ice cores, has enabled us to recognize the precise time at which major floods occurred at the Mediterranean continental shelf over the past $270 \mathrm{kyr}$.

The application of this approach to the sedimentary sections of marine isotope stage 3 has enabled identification of five flooding events which were observed at the onset of the warmest Greenland interstadials. The consistent correspondence between warm climate episodes and eustatic sea level rises shows that these events were generated by pronounced melting of the $\mathrm{NH}$ icesheets, due to rapid intensification of Atlantic Meridional Overturning Circulation.

In addition, the method described in this study opens a new perspective for inter hemispheric synchronization of marine climate records if applied in other continental margins, especially in the tropical Pacific, which may result in a leap forward towards understanding the effect of ocean heat transport on ice-sheet dynamics.

\section{Acknowledgements}

This work was supported by the European Comission Project PROMESS1 and the IMAGES program that funded the drilling and coring of the Gulf of Lion. Support from Junta de Castilla y León (Grupo GR34), Ministerio de Educacion y Ciencia (including CGL 2005-00642/BTE, CGL2008-05560, REN 2003-08642-CO2/CLI, several RTD projects, complementary actions and the Consolider Ingenio "GRACCIE" 
program CSD 2007-00067) and Generalitat de Catalunya are also acknowledged, as well as the French Agence Nationale de la Recherche (ANR, contract NT05-3-42040). The reviews by M. Siddall, H. Arz and F. Lamy greatly improved an earlier version of this manuscript.

\section{References}

Ahn, J., Brook, E. J., 2008. Atmospheric $\mathrm{CO}_{2}$ and Climate on Millennial Time Scales During the Last Glacial Period. Science, 322, 83-85.

Andersen, K. K., Svensson, A., Rasmussen, S. O., Steffensen, J. P., Johnsen, S. J., Bigler, M., R“othlisberger, R., Ruth, U., Siggaard-Andersen, M.-L., Dahl-Jensen, D., Vinther, B. M., and Clausen, H. B., 2006. The Greenland Ice Core Chronology 2005, 15-42 ka. Part 1: constructing the time scale. Quat. Sci. Rev. 25, 3246-3257.

Arz, H. W., Lamy, F., Ganopolski, A., Nowaczyk, N., Pätzold, J., 2007. Dominant Northern Hemisphere climate control over millennial-scale glacial sea-level variability. Quat. Sci. Rev. 26, 312-321.

Bassetti, M. A., Jouet, G., Dufois, F., Berne, S., Rabineau M., Taviani M., 2006. Sand bodies at the shelf edge in the Gulf of Lions (Western Mediterranean): Deglacial history and modern processes. Mar. Geol. 234, 93-109.

Bassetti, M. A., Berne, S., Jouet, G., Taviani, M., Dennielou, B., Flores, J.A., Gaillot, A., Gelfort, R., Lafuerza, S., Sultan N. 2008. The 100-ka and rapid sea level changes recorded by prograding shelf sand bodies in the Gulf of Lions (western Mediterranean Sea). Geochem. Geophys. Geosyst. 9, Q11R05, doi:10.1029/2007GC001854.

Berné, S., Carré, D., Loubrieu, B., Mazé, J. P., Normand A., 2002. Notice de la carte morpho-bathymétrique du Golfe du Lion, IFREMER et Région Languedoc Roussillon. Ifremer, Brest, pp. 0-48.

Berné, S., Jouet, G., Bassetti, M. A., Dennielou, B., Taviani, M. 2007. Late Glacial to Preboreal sea-level rise recorded by the Rhône deltaic system (NW Mediterranean). Mar. Geol. 245, 65-88.

Blunier, T., Brook, E. J. 2001. Timing of millennial-scale climate change in Antarctica and Greenland during the last glacial period. Science 291, 109-112.

Bond, G., Broecker, W.S., Johnsen S., McManus J., Labeyrie, L., Jouzel, J., Bonani, G., 2003. Correlations between climate records from North Atlantic sediments and Greenland ice. Nature 365, 143-147. 
Broecker, W. S. 1994. Massive iceberg discharges as triggers for global climate change Nature, 372, 421-424.

Broecker, W. S., 1998. Paleocean circulation during the last deglaciation A bipolar seasaw?. Paleoceanography 13, 119-121.

Cacho, I., Grimalt, J.O., Pelejero, C., Canals, M., Sierro, F.J., Flores, J.A., Shackleton, N., 1999. Dansgaard-Oeschger and Heinrich event imprints in the Alboran Sea paleotemperatures. Paleoceanography 14, 698-705.

Cacho, I., Grimalt, J.O., Sierro, F.J., Shackleton, N., and Canals, M. 2002. Evidence for enhanced Mediterranean thermohaline circulation during rapid climatic coolings. Earth Planet. Sci. Letters 183, 427-432.

Chappell, J., 2002. Sea level changes forced ice breakouts in the Last Glacial cycle: new results from coral terraces. 2002. Quat. Sci. Rev. 21, 1229-1240.

Clark, P. U., Hostetler, S. W., Pisias, N.G., Schmittner, A., Meissner K.J., 2007. Mechanisms for an $\sim 7$ kyr Climate and Sea Level Oscillation during Marine Isotope Stage 3. in Ocean Circulation Mechanisms and Impacts (eds. Schmittner, A., Chiang J.C.H. \& Hemming S.R.). AGU Geophysical Monograph 173, Washington, pp 209-246. Coplen, T. B., 1996. New guidelines for the reporting of stable hydrogen, carbon, and oxygen isotope ratio data. Geochim. Cosmochim. Acta 60, 3359-3360.

Dokken, T., Jansen, E., 1999. Rapid changes in the mechanism of ocean convection during the last glacial period. Nature 401, 458-461.

Fairbanks, R. G., 1989. A 17,000-year glacio-eustatic sea level record: influence of glacial melting rates on the Younger Dryas event and deep-ocean circulation. Nature, 342, 637-642.

Fairbanks, R. G., Mortlock, R.A., Chiu, T.C., Cao, L., Kaplan, A., Guilderson, T.P. Fairbanks, T.W., Bloom, A.L., Grootes P.M., Nadeau, M.J., 2005. Radiocarbon calibration curve spanning 0 to 50000 years BP based on paired 230Th/234U/ 238U and ${ }^{14} \mathrm{C}$ dates on pristine corals. Quat. Sci. Rev. 24, 1781-1796.

Gensous, B., Tesson, M., 1997. Les dépôts postglaciaires de la plateforme rhodanienne: organization stratigraphique et conditions de mise en place. Comptes Rendus de l’Académie des Sciences Paris-Série IIa 325, 695-701.

Gensous, B., Tesson, M., 2003. L’analyse des dépôts postglaciaires et son application à l'étude des séquences de dépôt du Quaternaire terminal sur la plate-forme au large du Rhône (Golfe du Lion). Bull. Soc. Geol. Fr. 174, 401-419. 
Hughen, K.A. et al., 2004. Marine04 Marine Radiocarbon age calibration, 0-26 cal kyr BP. Radiocarbon 46, 1059-1086.

Jouet, G. 2007. Enregistrements stratigraphiques des cycles climatiques et glacioeustatiques du Quaternaire terminal. Modelisations de la marge continentale du Golfe du Lion. These (unpublished). Université Bretagne Occidentale.vol I, 443 pp.

Jouet, G., Berné, S., Rabineau, M., Bassetti, M.A., Bernier, P., Dennielou, B., Sierro, F.J., Flores, J.A., Taviani, M., 2006. Shoreface migrations at the shelf edge and sealevel changes around the Last Glacial Maximum (Gulf of Lions, NW Mediterranean). Mar. Geol. 234, 21-42.

Jouet, G., Hutton, E.W.H., Syvitski, J.P.M., Berne, S. 2008. Response of the Rhone deltaic margin to loading and subsidence during the last climatic cycle. Computers \& Geosciences 34, 1338-1357.

Jouet, G., Berné, S., Sierro, F.J., Bassetti, M.A., Canals, M., Dennielou B., Flores, J.A., Haq, B. and the Promess-1 Team. Stratigraphic signature of millennial-scale sea-level changes. Submitted to Science.

Kageyama, M., and Paillard, D. 2005. Dansgaard-Oeschger events: an oscillation of the climate-ice-sheet system?. C. R. Geosciences 337, 993-1000.

Labaune, C., Jouet, G., Berne, S., Gensous, B., Tesson, M., Delpeint, A., 2005. Seismic stratigraphy of the Deglacial deposits of the Rhone prodelta and of the adjacent shelf. Mar. Geol. 222-223, 299-311.

Labaune, C., Tesson, M., Gensous, B., 2008. Variability of the transgressive stacking pattern under environmental changes control: Example from the Post-Glacial deposits of the Gulf of Lions inner-shelf, Mediterranean, France. Cont. Shelf Res. 28, 11381152.

Lambeck, E., Bard, E., 2000. Sea-level change along the French Mediterranean coast for the past 30,000 years. Earth Planet. Sci. Lett. 175, 203-222.

Loutit, T. S., Hardenbol, J., Vail, P. R., Baum, G. R., 1988. Condensed sections: the key to age determination and correlation of continental margin sequences. in Sea-level Changes: An Integrated Approach (eds. Wilgus, C. K. et al.). Soc. Econ. Paleontol. Mineral. Spec. Publ.42, Tulsa. pp 183-213.

Martinson, D.G., Pisias, N. G., Hays, J. D., Moore, T. C.jr., Shackleton, N. J., 1987. Age Dating and the Orbital Theory of the Ice Ages: Development of a High-Resolution 0 to 300,000 Year Chronostratigraphy. Quat. Res. 27, 1-89. 
Martrat, B., Grimalt, J. O., Lopez-Martinez, C., Cacho, I., Sierro, F.J., Flores, J.A., Zahn, R., Canals, M., Curtis, J.H., Hodell, D. 2004. Abrupt temperature changes in the Western Mediterranean over the past 250,000 years. Science 306, 1762-1765.

Martrat, B., Grimalt, J. O., Shackleton, N. J., Abreu, L., Hutterli, M. A., Stocker, T.F., 2007. Four Climate Cycles of Recurring Deep and Surface Water Destabilizations on the Iberian Margin. Science 317, 502-507.

North Greenland Ice Core Project members. 2004. High resolution climate record of the northern hemisphere reaching into the last interglacial period. Nature 431, 147-151.

Perez-Folgado, M., Sierro, F.J., Flores, J. A., Cacho, I., Grimalt, J. O., Zahn, R., Shackleton, N.J., 2003. Western Mediterranean planktic foraminifera events and millennial climatic variability during the last 70 kyr. Mar. Micropaleontol. 48, 49- 70.

Peterson, L. C., Haug, G.H., Hughen, K.A., Röhl, U., 2000. Rapid changes in the hydrologic cycle of the tropical Atlantic during the last glacial. Science 290, 1947-1951. Posamentier, H. W., Allen, G. P., James, D.P., Tesson, M., 1992. Forced regression in a sequence stratigraphic framework: concepts, examples and exploration significance. AAPG Bull. 76, 1687-1709.

Rabineau, M., Berne, S., Ledrezen, E., Lericolais, G., Marsset, T., Rotunno, M., 1998. 3D architecture of lowstand and transgressive Quaternary sand bodies on the outer shelf of the Gulf of Lion, France. Mar. Petr. Geol. 15, 439-452.

Rabineau, M., Berne, S., Aslanian, D., Olivet, J.L., Joseph, P., Guillocheau, F., Bourillet, J.F., Ledrezen E., Granjeon, D., 2005. Sedimentary sequences in the Gulf of Lion: a record of 100,000 years climatic cycles. Mar. Petr. Geol. 22, 775-804.

Rabineau, M., Berne, S., Olivet, J. L., Aslanian, D., Guillocheau, F., Joseph, P., 2006. Paleo sea levels reconsidered from direct observation of the paleoshoreline position during Glacial Maxima (for the last 500,000 yr). Earth Planet. Sci. Lett. 252, 119-137. Roche, D., Paillard, D., Cortijo E., 2004. Constraints on the duration and freshwater release of Heinrich event 4 through isotope modelling. Nature 432, 379-382.

Rohling, E. J., Grant, J. K., Hemleben, C., Kucera, M., Roberts, A. P., Schmeltzer, I., Schulz, H., Siccha, M., Siddall, M., Trommer, G. 2008. New constraints on the timing of sea level fluctuations during early to middle marine isotope stage 3 . Paleoceanography 23, PA3219, doi:10.1029/2008PA001617.

Schmittner, A., Yoshimori, M., Weaver, A.J., 2002. Instability of glacial climate in a model of the ocean-atmosphere-cryosphere system. Science 295, 1489-1493. 
Shackleton, N. J., 2000. The 100,000-year ice-age cycle identified and found to lag temperature, carbon dioxide, and orbital eccentricity. Science 289, 1897-1902.

Shackleton, N. J., Hall, M. A., Vincent, E., 2000. Phase relationships between millennial scale events 64000 to 24000 years ago. Paleoceanography 15, 565-569.

Shackleton, N. J., Fairbanks, R. G., Chiu, Tzu-Chien, Parrenin, F, 2004. Absolute calibration of the Greenland time scale: implications for Antarctic time scales and for $\Delta^{14}$ C. Quat. Sci. Rev., 23, 1513-1522.

Siddall, M., Rohling E. J., Almogi-Labin, A., Hemleben Ch., Meischner D., Schmelzer I., Smeed, D. A., 2003. Sea-level fluctuations during the last glacial cycle. Nature 423, 853-858.

Siddall, M., Rohling, E. J., Thompson, W. G., and Waelbroeck C. 2008. Marine isotope stage 3 sea level fluctuations: data synthesis and new outlook. Rev. Geophys., 46, RG4004, doi:10.1029/2007RG000233.

Sierro, F. J., Flores, J. A., Baraza, J. 1999. Late glacial to recent paleoenvironmental changes in the Gulf of Cadiz and formation of sandy contourite layers. Mar. Geol. 155, 157-172.

Sierro, F. J., Hodell, D.A., Curtis, J.H., Flores, J.A., Reguera, I., Colmenero-Hidalgo E., Barcena, M.A., Grimalt, J.O., Cacho, I., Frigola, J., Canals, M., 2005. Impact of iceberg melting on Mediterranean thermohaline circulation during Heinrich events. Paleoceanography 20, PA2019, doi:10.1029/2004PA001051.

Skinner, L. C., Shackleton, N. J., Elderfield, H., 2003. Millennial-scale variability of deep-water temperature and d18Odw indicating deep-water source variations in the northeast Atlantic, 0-34 cal ka BP. Geochem. Geophys. Geosyst. 4(12), 1098, doi:10.1029/2003GC000585.

Skinner, L. C., Elderfield, H., 2007. Rapid fluctuations in the deep North Atlantic heat Budget during the last glacial period. Paleoceanography 22, art no. PA1205, doi:10.1029/2006PA001338.

Svensson, A., Andersen, K. K., Bigler, M., Clausen, H. B., Dahl-Jensen, D., Davies, S. M., Johnsen, S. J., Muscheler, R., Parrenin, F., Rasmussen, S. O., Röthlisberger, R. Seierstad, I., Steffensen J. P., Vinther, B. M., 2008. A 60000 year Greenland stratigraphic ice core chronology. Clim. Past. 4, 47-57.

Tesson, M., Gensous, B., Allen, G., Ravenne, C., 1990. Late quaternary deltaic lowstand wedges on the Rhône continental shelf France. Mar. Geol. 91, 325-332. 
Tesson, M., Allen, G. P., Ravenne, C., 1993. Late Pleistocene shelf-perched lowstand wedges on the Rhone continental shelf. In: Posamentier, H. W., Haq, B.A., Allen, G.P. (Eds.), Sequence Stratigraphy and Facies Associations. IAS Special Publication, Oxford, pp. 183-196.

Tesson, M., Posamentier, H., Gensous, B., 2000. Stratigraphic Organization of the Late Pleistocene Deposits of the Western Part of the Golfe du Lion Shelf (Languedoc shelf), Western Mediterranean Sea, using high Resolution Seismic and Core Data. AAPG Bull. 84, 119-150.

Thompson, W. G., Goldstein, S. L., 2005. Open-system coral ages reveal persistent suborbital sea-level cycles. Science 308, 401-404, doi:10.1126/science.1104035. Thompson, W. G., Goldstein, S. L., 2006. A radiometric calibration of the SPECMAP timescale, Quat. Sci. Rev., 25(23-24), 3207-3215, doi:10.1016/j.quascirev.2006.02.007.

Vidal, L., Labeyrie, L., Van Weering T.C.E., 1998. Benthic $\delta^{18} \mathrm{O}$ records in the North Atlantic over the last Glacial Period (60-10 kyr): evidence for brine formation. Paleoceanography 13(3), 245-251.

Waelbroeck, C., L. Labeyrie, L., Michel, E., Duplessy, J. C., McManus, J. F., Lambeck, K., Balbon, E., Labracherie, M., 2002. Sea-level and deep water temperature changes derived from benthic foraminifera isotopic records. Quat. Sci. Rev. 21, 295-305.

Weninger, B., Jöris, O., 2008. Towards an Absolute Chronology at the Middle to Upper Palaeolithic Transition in Western Eurasia: A New GreenlandHulu Time-scale Based on U/Th Ages. Journal of Human Evolution 55, 772-781.

Yokoyama, Y., Esat, T. M., Lambeck, K., 2001. Coupled climate and sea-level changes deduced from Huon Peninsula coral terraces of the last ice age, Earth Planet. Sci. Lett., 193, 579-587, doi:10.1016/S0012-821X(01)00515-5.

\section{Figure legends.}

Figure 1. Map showing the bathymetry, coastal rivers and sand distribution in the Gulf of Lion (from Berné et al., 2002) as well as the location of sediment core MD99-2348 and Hole PRGL1. The location of PSL 1 and PSL2 during the Younger Dryas and the Late Holocene, respectively are indicated. Paleo-rivers during the last glaciation are also drawn. 
Figure 2. Modified from Jouet (2007). Synthetic stratigraphic section across the Gulf of Lions, illustrating the overall progradation of the deltaic system during MIS3 and MIS2 and retrogradation during the deglaciation. Coastal deltaic deposits are shown in yellow, while pelitic prodeltaic sediments are shown in grey. The Bolling-AllerodYounger Dryas deltaic system and PSL2 is seen in the middle shelf, while the late Holocene deltaic system and PSL1 can be seen in the inner shelf, near the present coastline. The red line from the inner shelf to the slope indicates the recent condensed layer. The position of borehole/core PRGL1-MD99-2348 is indicated. Names of seismic reflectors and seismic units together with their ages are shown in the figure. Although many of these units are not mentioned in the text they are shown to facilitate comparisons with other papers referenced in the text. Note that the vertical scale is strongly exaggerated. The figure was modified from Jouet 2008.

Figure 3. Formation of the recent condensed layer in response to the high sea level of the last $14.5 \mathrm{kyr}$. (A) G. bulloides $\delta^{18} \mathrm{O}$ record versus depth in core MD99-2348 during the LGM and Termination I. (B) Percent of fine-sand along core MD99-2348 showing a prominent maximum in the uppermost $50 \mathrm{~cm}$ due to the formation of a CL during the last 14.5 kyr. (C) Number of planktic foraminifers per gram of dry sediment that shows a prominent increase within the CL due to extremely low terrigenous river supply. Numbers show the calibrated ${ }^{14} \mathrm{C}$ ages. Gray bar on top marks the youngest CL.

Figure 4. Relationship between global sea level and formation of condensed layers over the last 270 kyr. (A) Percent of fine sand versus depth in the composite record of core MD99-2348 and borehole PRGL1. Gray bars indicate timing of CLs characterized by fine sand peaks. The uppermost CL is shown in figure 3. (B) Percent of fine sand versus age. (C) Number of planktic foraminifers per gram. The number of shells increases within the CL due to extremely low terrigenous river supply. (D, E) Global sea level records (Siddall et al., 2003; Waelbroeck et al., 2002). (F) $\delta^{18} \mathrm{O}$ record of Globigerina bulloides. (G) Sedimentation rate. Dashed lines indicate the CLs during the last glaciation shown in figure 7. Numbers on top indicate Marine Isotope Stages (MIS). Numbers on bottom show the calibrated ${ }^{14} \mathrm{C}$ ages in ka.

Figure 5. Evidence of flooding events and millennial climate change during the last interglacial period in the Gulf of Lions continental shelf. (A) $\delta^{18} \mathrm{O}$ ice record of the 
NGRIP ice core that reflects temperature changes in Greenland. (B) and (C) Globigerina bulloides and Hyalinea balthica $\delta^{18} \mathrm{O}$ (planktic and benthic) records using NGRIP chronology (Svensson et al., 2008). (D) Percent of temperate to warm planktic foraminifers reflecting sea surface changes in Mediteranean temperature. (E) Percent of fine sand showing three prominent peaks in GIS 26, 24 and 21 and a small one in GIS 23, which indicate condensation due to rapid landward coastal migration at times of rapid sea level rise. Numbers on top indicate the Marine Isotope Stages. Numbers on bottom show Greenland interstadials.

Figure 6. Age-depth plot of borehole PRGL1 for the interval from 25 to $65 \mathrm{kyr}$ ago, showing the tie points used to synchronize the Gulf of Lions foraminifer and oxygen isotope records with NorthGrip ice Core. Depth in meters below sea floor.

Figure 7. Flooding events during the last glacial period occurred during the longest Greenland interstadials. (A) NorthGrip $\delta^{18} \mathrm{O}$ ice record that reflects temperature changes in Greenland (Svensson et al., 2008). (B) Percent of temperate to warm planktic foraminifers in Hole PRGL1. (C) $\delta^{18} \mathrm{O}$ record of Globigerina bulloides. (D) Percent of the polar species Neogloboquadrina pachyderma sinistral (N. pac. sin.). (E) Percent of fine sand. (F) Number of planktic foraminifers per gram. (G) Record of SST in ODP Site 977 (Alboran Sea)(Martrat et al. 2004).

Figure 8. Plot of AMS ${ }^{14} \mathrm{C}$ ages, calibrated ages and NorthGrip tuned ages versus composite depth in core MD99-2348 and Hole PRGL1.

Figure 9. Phase relationship between sea level and abrupt climate change. (A) NorthGrip $\delta^{18} \mathrm{O}$ ice record that reflects temperature changes in Greenland (Svensson et al., 2008). (B) Percent of fine sand. (C) Sedimentation rate record. (D) Siddall et al., (2003) and Arz et al., (2007) sea level records with a new age scale derived from the synchronization to the Gulf of Lions CLs record. The Red sea age scales were transformed by assigning new ages to the midpoints of the major sea level rises, assuming that they were isochronous with the bottom of our CLs (CLs of GIS 16, GIS 14, GIS 12, GIS 8, GIS 7). (E) Siddall et al. (2003) sea level record plotted on NorthGrip time scale. (F) Arz et al. (2007) sea level record plotted on NorthGrip time 
scale. Arrows indicate the phase correction needed to synchronize both Red Sea sea level records with the Gulf of Lions.

Figure 10. (A) NorthGrip $\delta^{18} \mathrm{O}$ ice record that reflects temperature changes in Greenland (Svensson et al., 2008). (B) Percent of fine sand. (C) Sedimentation rate record, illustrating four short-term cycles of sea level lowering (ice growth). (D) Atmospheric $\mathrm{CO}_{2}$ record from Taylor Dome ice core plotted on NorthGrip time scale (Ahn and Brook 2007). (E) Benthic $\delta^{13} \mathrm{C}$ in core 2042 from the deep NA, a proxy for changes in the AMOC (Shackleton et al., 2000). (F) $\delta^{18} \mathrm{O}$ ice record of the Byrd ice core plotted on NorthGrip time scale (Blunier and Brook 2001), Antarctica. A1 to A4 show warming events in Antarctica. Gray bars indicate timing of millennial flooding events. Green bars indicate timing of Heinrich events. Numbers on bottom indicate Greenland interstadials.

Table 1. List of radiocarbon dated samples in core MD99-2348 and borehole PRGL1, showing radiocarbon and calibrated ages in years. Depth is shown in cm bsf (below sea floor).

Table 2. List of climatic and oxygen isotope events used for the elaboration of the age model with North Grip and SPECMAP ages. (1) Climatic events reported by Martrat et al. 2004 for the western Mediterranean. GIS = Greenland interstadials. Gs = Greenland stadials. 
Table 1

\begin{tabular}{|c|c|c|c|}
\hline \multicolumn{4}{|c|}{ Core MD99-2348 } \\
\hline \multirow{2}{*}{$\begin{array}{c}\text { Sample depth } \\
\text { (cm bsf) }\end{array}$} & \multirow{2}{*}{$\begin{array}{c}\begin{array}{c}\text { Conventional } \\
\text { BP) }\end{array} \\
13,020 \pm 40\end{array}$} & \multicolumn{2}{|c|}{$\begin{array}{c}\text { Calibrated age (yr BP) } \\
\text { (1 sigma) }\end{array}$} \\
\hline & & $14,700-14,964$ & Hughen et al 2004 \\
\hline 80 & $14,350 \pm 60$ & $16,382-16,791$ & Hughen et al 2004 \\
\hline 190 & $14,640 \pm 60$ & $16744-17,164$ & Hughen et al 2004 \\
\hline 300 & $15,380 \pm 70$ & $18,304-18,486$ & Hughen et al 2004 \\
\hline 360 & $14,960 \pm 70$ & $17,301-17,766$ & Hughen et al 2004 \\
\hline 518 & $15,890 \pm 70$ & $18,729-18,850$ & Hughen et al 2004 \\
\hline 748 & $16,600 \pm 70$ & $19,276-19,450$ & Hughen et al 2004 \\
\hline 1018 & $17,910 \pm 80$ & $20,457-20,764$ & Hughen et al 2004 \\
\hline 1231 & $18,060 \pm 60$ & 20,611-20,956 & Hughen et al 2004 \\
\hline 1,498 & $19,750 \pm 90$ & $22,663-23,131$ & Hughen et al 2004 \\
\hline 1,680 & $20,560 \pm 80$ & $23,964-24,237$ & Hughen et al 2004 \\
\hline 2,058 & $21,240 \pm 110$ & $24,855-25,332$ & Hughen et al 2004 \\
\hline 2,218 & $21,150 \pm 120$ & $24,618-25,308$ & Hughen et al 2004 \\
\hline \multicolumn{4}{|c|}{ Hole PRGL1 } \\
\hline $\begin{array}{l}\text { Sample depth } \\
\text { (cm bsf) }\end{array}$ & $\begin{array}{c}\text { Conventional }{ }^{14} \mathrm{C} \text { age (yr } \\
\text { BP) }\end{array}$ & \multicolumn{2}{|c|}{$\begin{array}{c}\text { Calibrated age (yr BP) } \\
\text { (1 sigma) }\end{array}$} \\
\hline $1,964.3$ & $20,330 \pm 120$ & $23,677-24,030$ & Hughen et al 2004 \\
\hline $2,568.2$ & $24,070 \pm 140$ & $28,129-28,547$ & Fairbanks0107 \\
\hline $2,666.4$ & $24,200 \pm 150$ & $28,268-28,700$ & Fairbanks0107 \\
\hline $2,754.0$ & $24,000 \pm 150$ & $28,041-28,479$ & Fairbanks0107 \\
\hline $2,968.0$ & $25,660 \pm 140$ & $30,182-30,592$ & Fairbanks0107 \\
\hline $3,110.0$ & $26,180 \pm 180$ & $30,735-31,201$ & Fairbanks0107 \\
\hline $3,242.7$ & $28,000 \pm 220$ & $32,635-33,201$ & Fairbanks0107 \\
\hline 3,403.6 & $29,690 \pm 260$ & $34,387-34,981$ & Fairbanks0107 \\
\hline $3,565.2$ & $30,760 \pm 250$ & $35,451-35,985$ & Fairbanks0107 \\
\hline $3,670.0$ & $33,800 \pm 400$ & $38,344-39,182$ & Fairbanks0107 \\
\hline $4,088.4$ & $38,200 \pm 600$ & $42,254-43,340$ & Fairbanks0107 \\
\hline $4,202.4$ & $35,800 \pm 500$ & $40,196-41,184$ & Fairbanks0107 \\
\hline $4,406.7$ & $39,500 \pm 800$ & $43,197-44,637$ & Fairbanks0107 \\
\hline $4,595.6$ & $41,100 \pm 900$ & $44,503-46,127$ & Fairbanks0107 \\
\hline $4,789.1$ & $46,100 \pm 2800$ & $46,341-53,381$ & CalPal-2007 \\
\hline $4,907.9$ & $46,300 \pm 1700$ & $46,960-52,036$ & CalPal-2007 \\
\hline
\end{tabular}




\begin{tabular}{|c|c|c|}
\hline Event & $\begin{array}{l}\text { PRGL1 depth } \\
\text { (m) }\end{array}$ & $\begin{array}{l}\text { Age NGRIP and } \\
\text { SPECMAP (kyr) }\end{array}$ \\
\hline Base Gis 2 & 19.74 & 23.28 \\
\hline$\delta^{18} \mathrm{O}$ maximum & 25.05 & 25.82 \\
\hline Top Gis 3 & 27.46 & 27.46 \\
\hline Base Gis 3 & 27.99 & 27.84 \\
\hline Top Gis 4 & 28.90 & 28.50 \\
\hline Base Gis 4 & 29.50 & 28.90 \\
\hline Peak Gis 4.1 & 31.56 & 30.72 \\
\hline Top Gis 5 & 32.88 & 32.04 \\
\hline Base Gis 5 & 33.30 & 32.52 \\
\hline Top Gis 6 & 33.86 & 33.38 \\
\hline Base Gis 6 & 34.30 & 33.80 \\
\hline Top Gis 7 & 35.30 & 34.72 \\
\hline Base Gis 7 & 35.65 & 35.46 \\
\hline Top Gis 8 & 36.18 & 36.60 \\
\hline Base Gis 8 & 36.75 & 38.24 \\
\hline Top Gis 9 & 37.77 & 39.96 \\
\hline Base Gis 9 & 38.13 & 40.16 \\
\hline Top Gis 10 & 39.56 & 41.10 \\
\hline Base Gis 10 & 40.08 & 41.50 \\
\hline Top Gis 11 & 40.88 & 42.13 \\
\hline Base Gis 11 & 42.12 & 43.33 \\
\hline Top Gis 12 & 43.00 & 44.33 \\
\hline Base Gis 12 & 44.65 & 46.98 \\
\hline Top Gis 13 & 46.12 & 48.16 \\
\hline Base Gis 13 & 47.46 & 49.28 \\
\hline Top Gis 14 & 48.98 & 51.68 \\
\hline Base Gis 14 & 49.50 & 54.22 \\
\hline Top Gis 15 & 50.39 & 55.42 \\
\hline Base Gis 15 & 50.66 & 55.78 \\
\hline Top Gis 16 & 51.38 & 56.38 \\
\hline Base Gis 16 & 52.37 & 58.32 \\
\hline Base Gis 17 & 53.60 & 59.44 \\
\hline Top Gis 18 & 58.56 & 63.90 \\
\hline Base Gs 19 & 63.59 & 70.70 \\
\hline Base Gis 19 & 63.90 & 72.40 \\
\hline Base Gs 20 & 63.99 & 74.05 \\
\hline Base Gis 20 & 64.25 & 76.40 \\
\hline Base Gs 21 & 64.98 & 77.85 \\
\hline Base Gis 21 & 65.59 & 84.80 \\
\hline Top Gis 22 & 66.14 & 87.75 \\
\hline Base Gis 22 & 66.50 & 90.10 \\
\hline Base Gis 23 & 67.30 & 104.05 \\
\hline Base Gs 24 & 67.90 & 105.45 \\
\hline Base Gis 24 & 68.70 & 108.30 \\
\hline Base Gs 25 & 69.99 & 110.65 \\
\hline Base Gs 26 & 71.20 & 118.70 \\
\hline MIS 5.53 & 72.27 & 126.00 \\
\hline Termination II & 72.45 & 133.00 \\
\hline Base warming event $3^{\prime}$ (1) & 103.27 & 149.60 \\
\hline Top MIS 6.5 & 110.88 & 162.00 \\
\hline Warming event 6́ (1) & 112.08 & 165.42 \\
\hline Warming event $7^{\prime}$ (1) & 112.87 & 170.77 \\
\hline Base MIS 6.5 & 114.47 & 175.05 \\
\hline Cooling event 9' (1) & 117.88 & 180.00 \\
\hline Warming event $9^{\prime}(1)$ & 119.12 & 181.41 \\
\hline Base cooling event $9^{\prime}(1)$ & 121.76 & 184.00 \\
\hline Top cooling event 10’ (1) & 123.11 & 186.72 \\
\hline Top MIS 7 & 123.44 & 191.00 \\
\hline MIS 7.1 & 124.09 & 201.00 \\
\hline MIS 7.2 & 125.37 & 205.00 \\
\hline MIS 7.3 & 125.75 & 217.00 \\
\hline Base MIS 7.3 & 125.97 & 222.52 \\
\hline Top MIS 7.5 & 127.36 & 232.00 \\
\hline Termination III & 127.75 & 247.00 \\
\hline Bottom MIS 8.43 & 142.00 & 266.00 \\
\hline Top MIS 8.5 & 157.10 & 279.00 \\
\hline
\end{tabular}




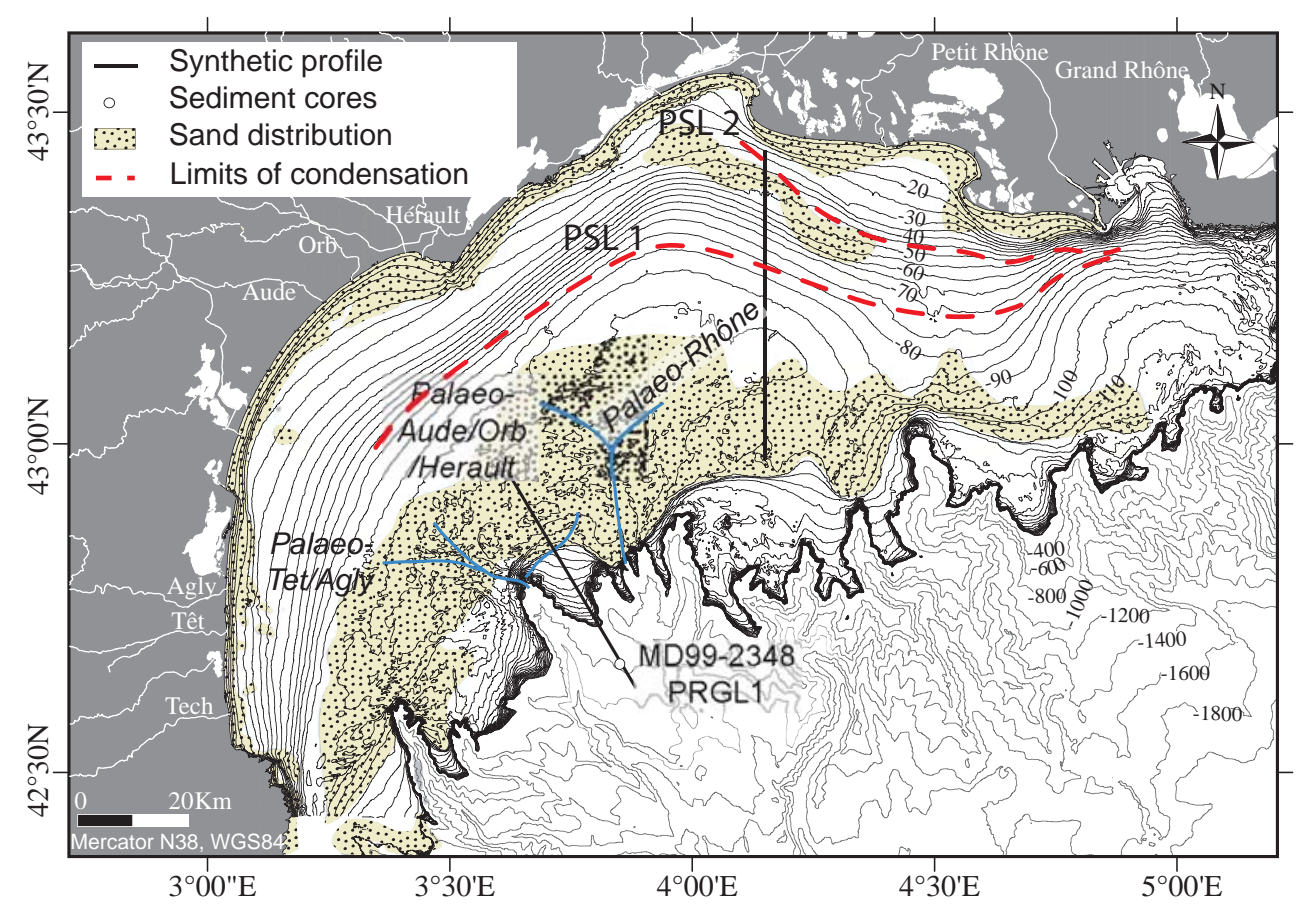

Figure 1 
Figure 2

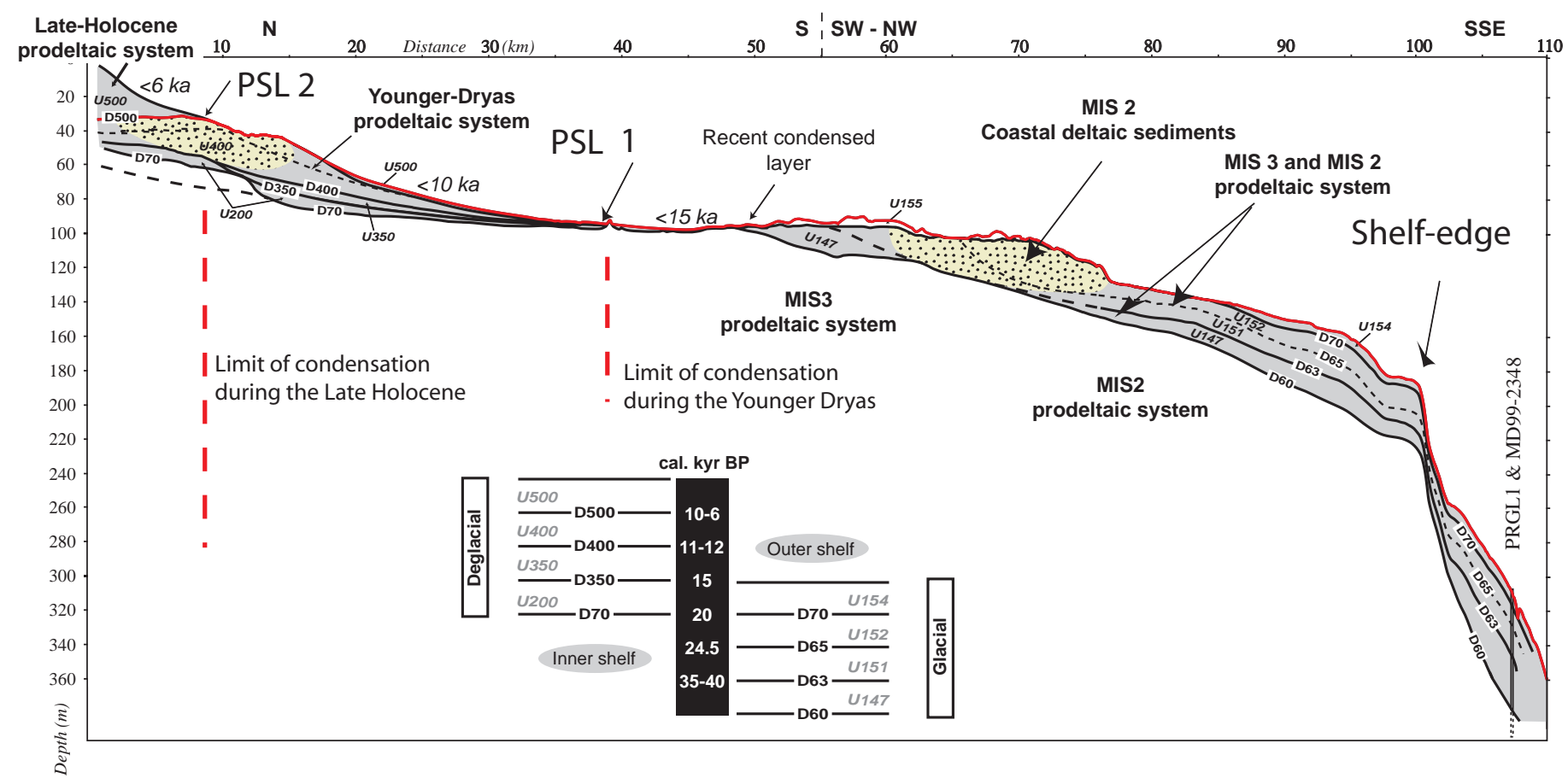

Figure 2 
Figure 3

Figure 3

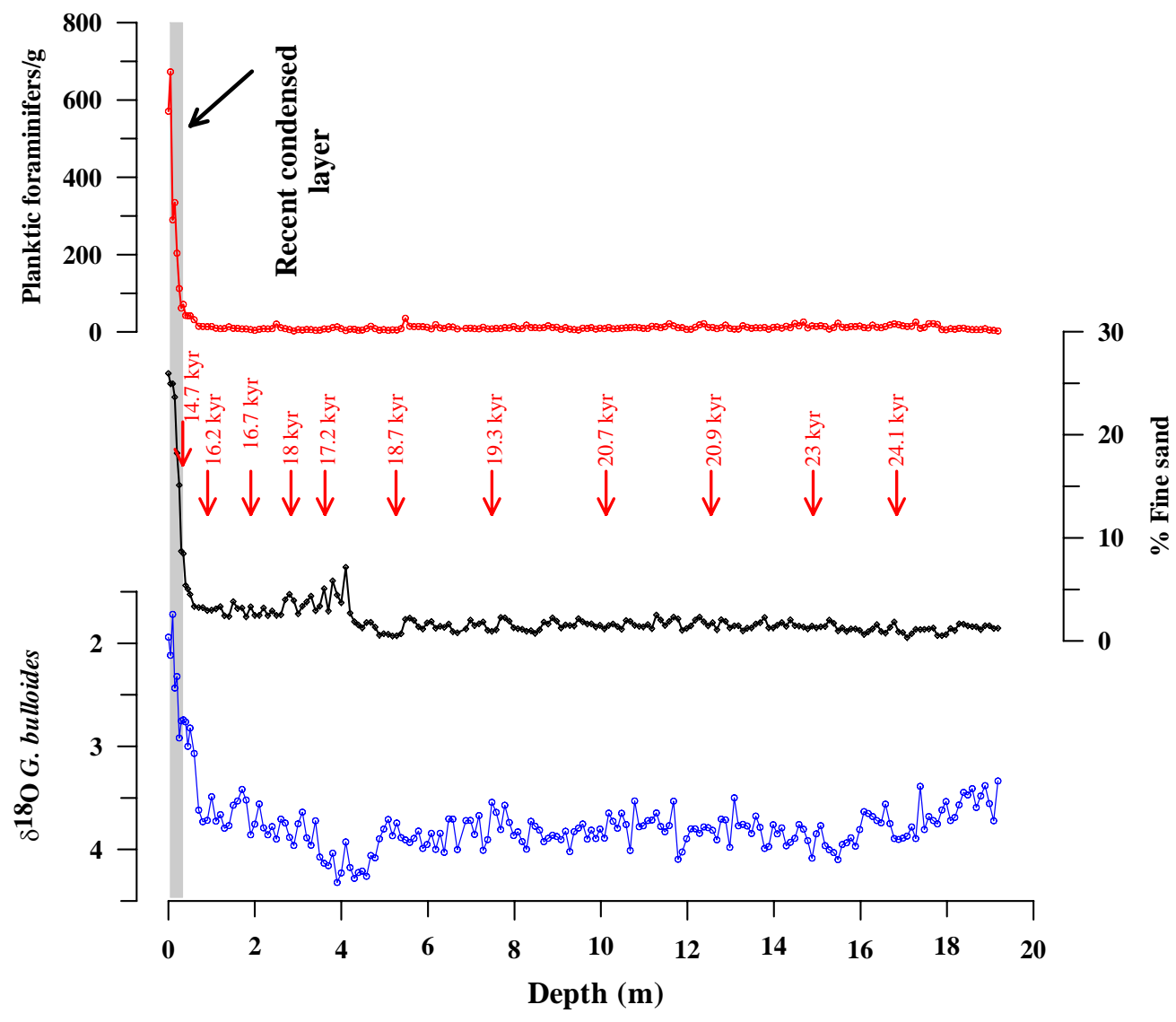


Figure 4

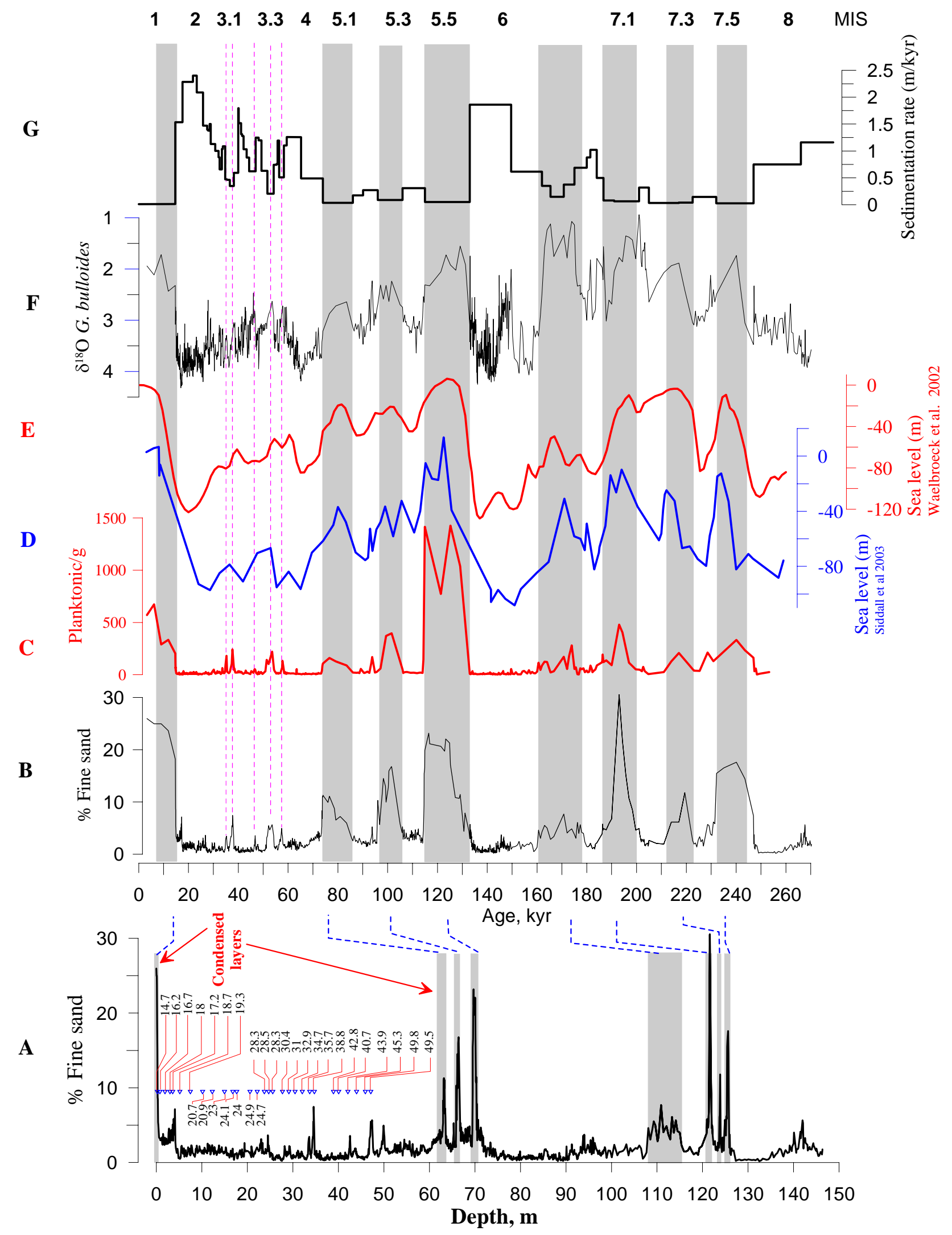


Figure 5

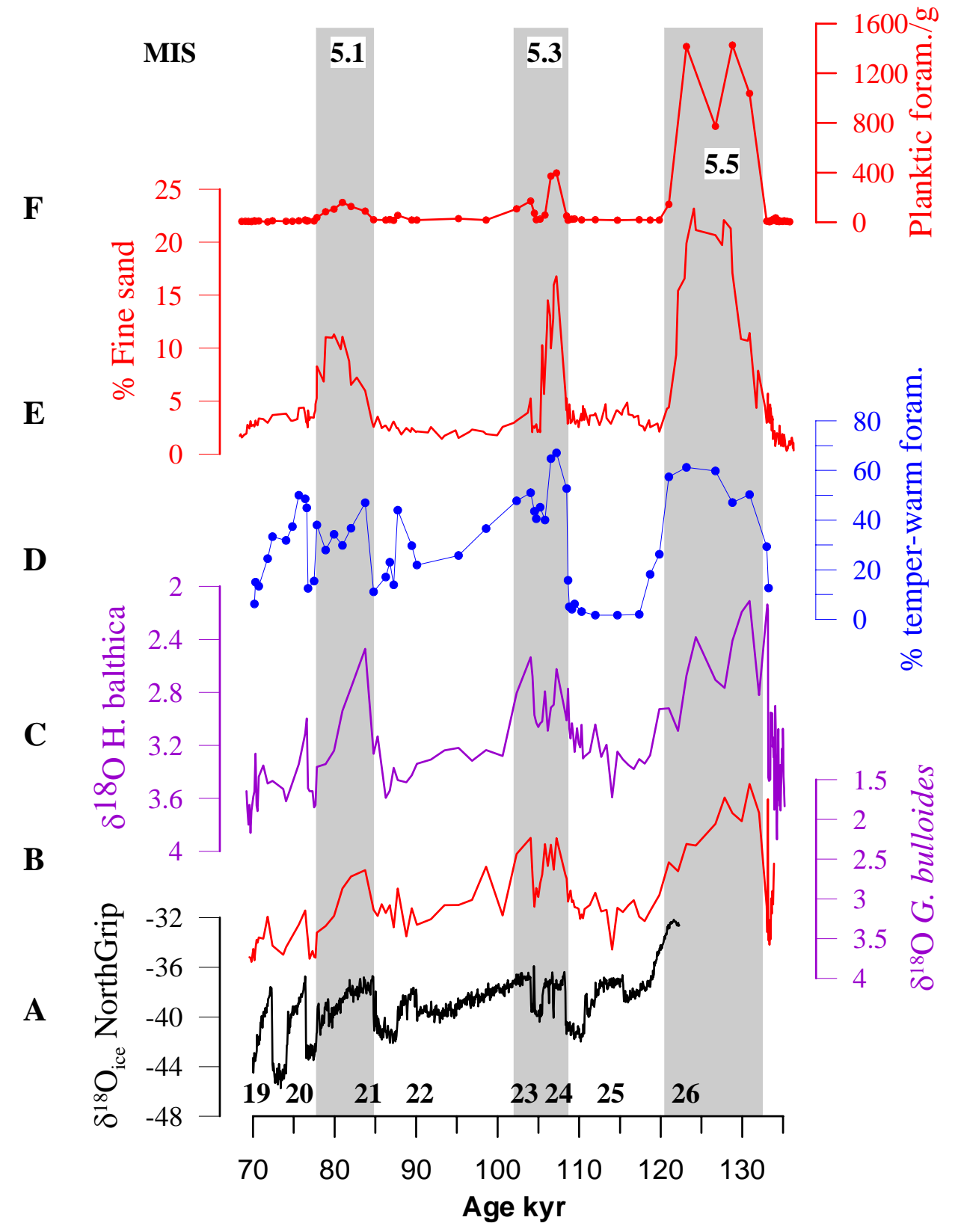


Figure 6

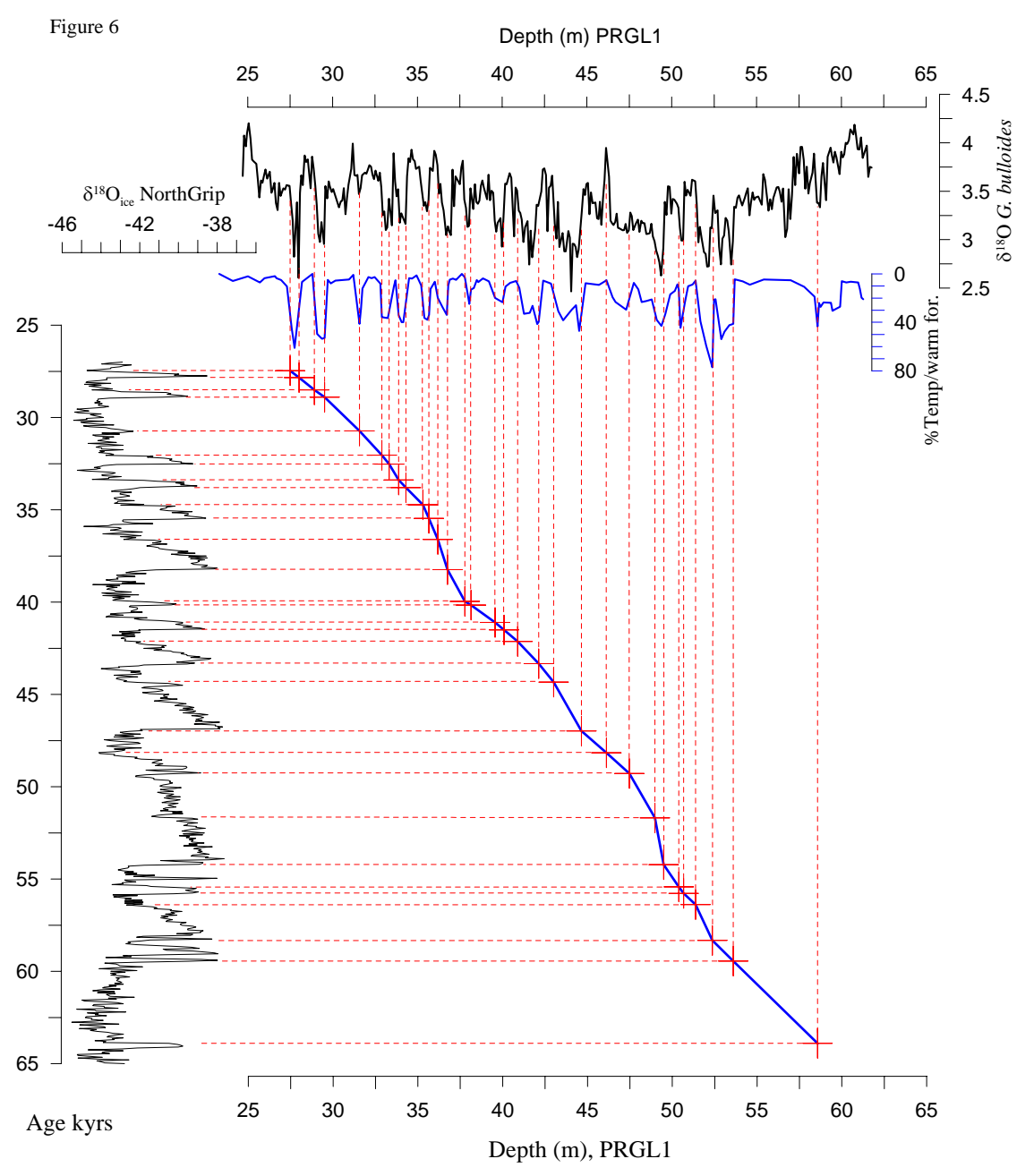


Figure 7

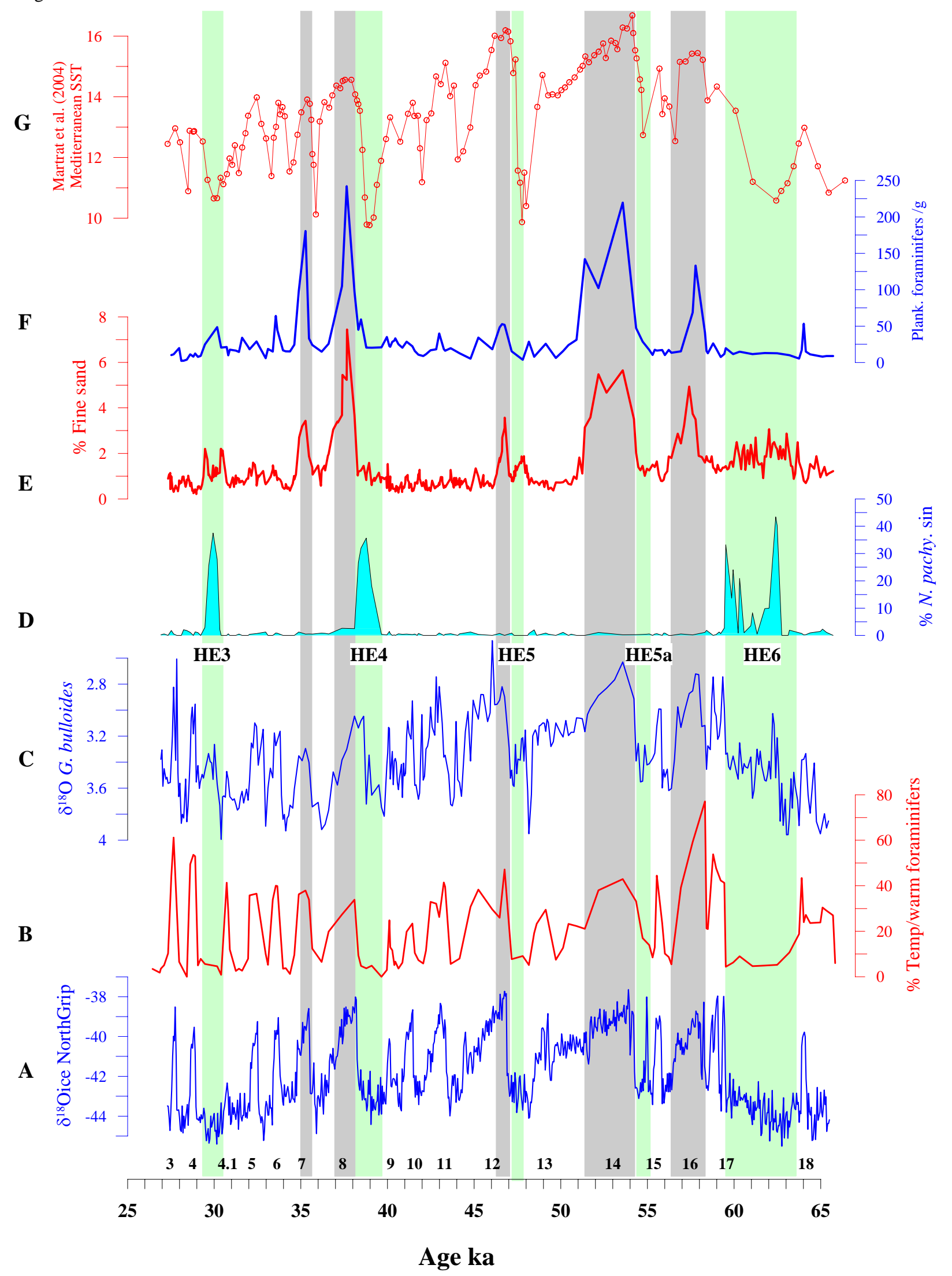


Figure 8

Figure 8

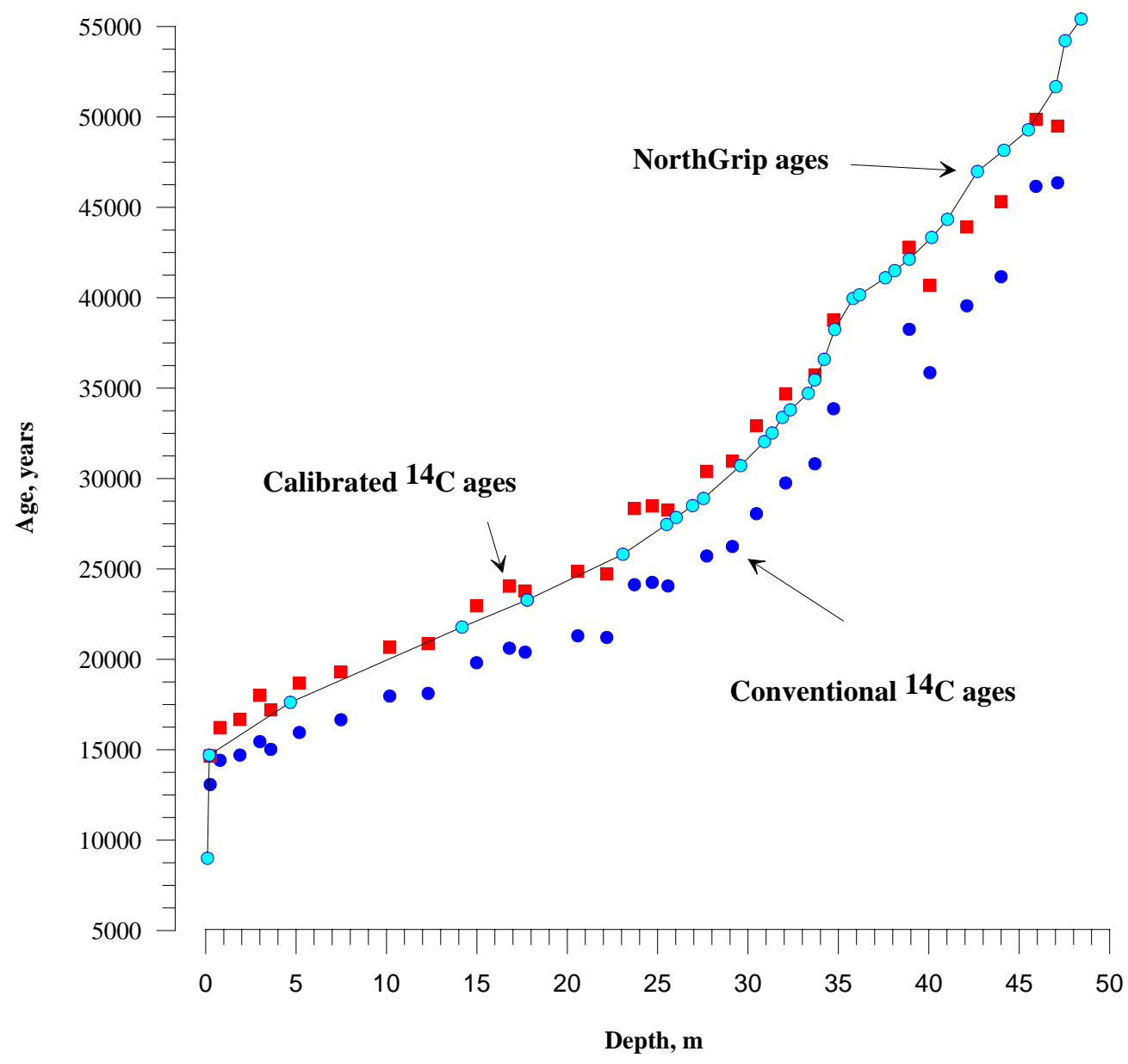




\section{Figure 9}

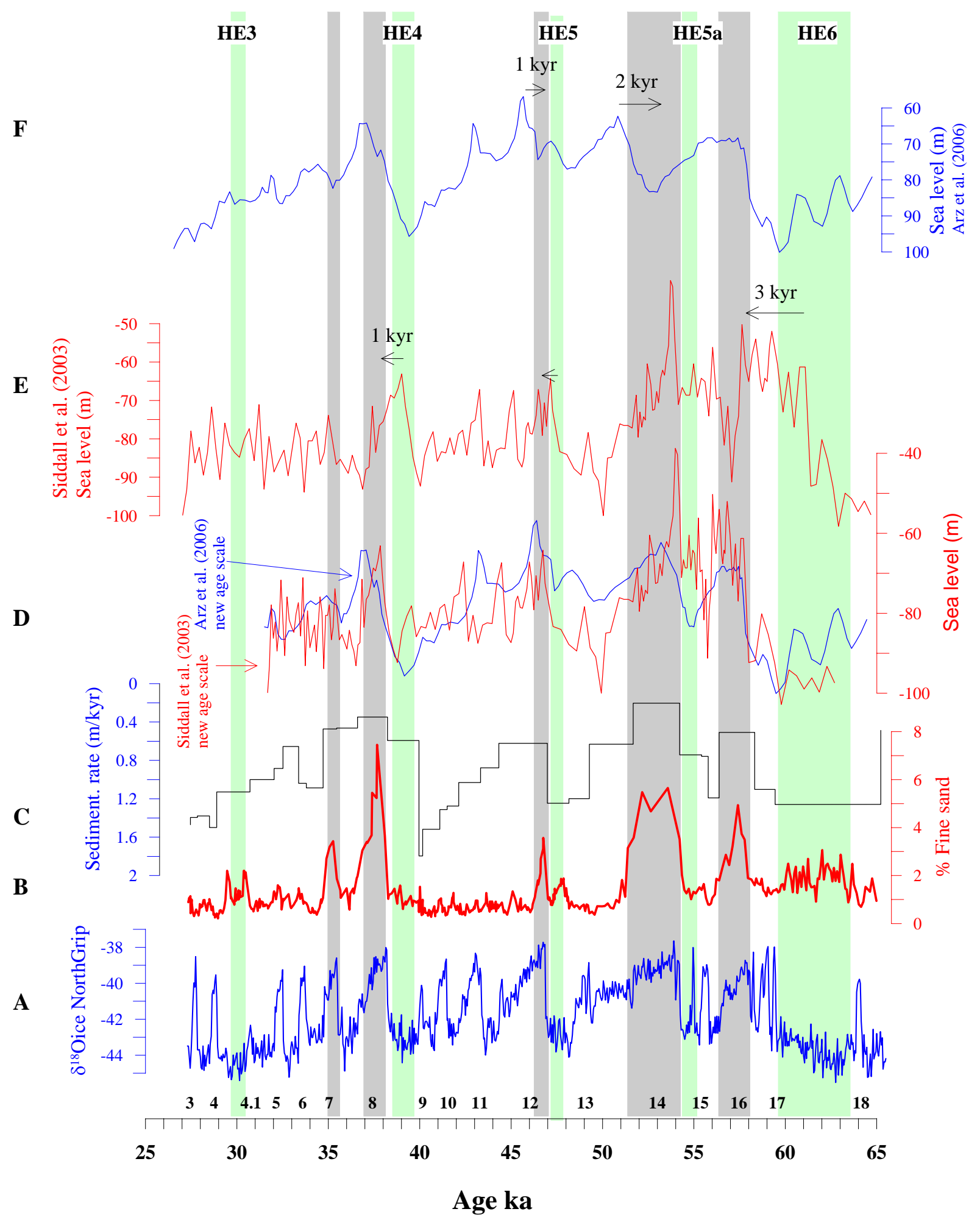


Figure 10

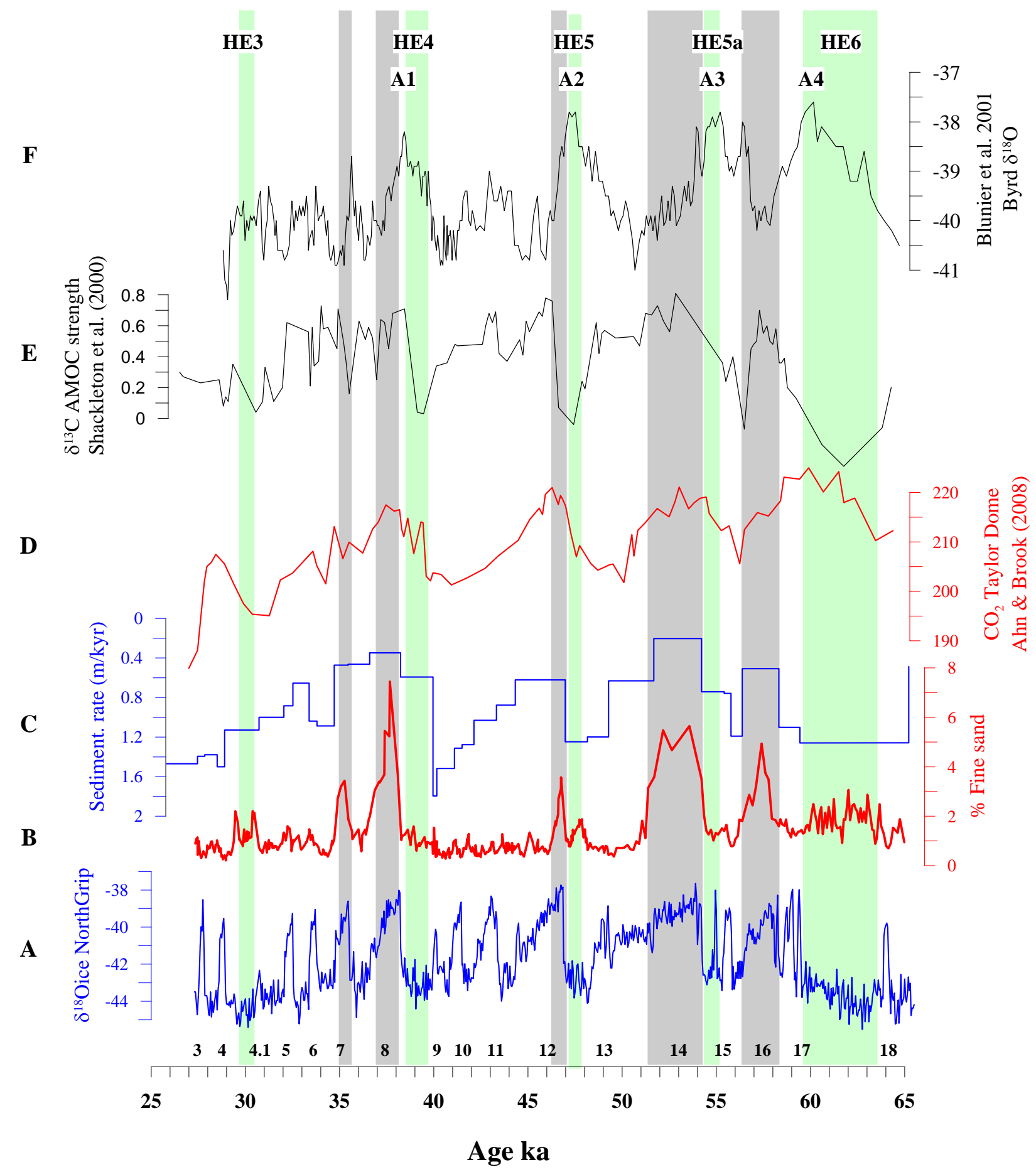

